\title{
The role of benthic foraminifera in the benthic nitrogen cycle of the Peruvian oxygen minimum zone
}

\author{
N. Glock ${ }^{1,2}$, J. Schönfeld ${ }^{2}$, A. Eisenhauer ${ }^{2}$, C. Hensen ${ }^{2}$, J. Mallon ${ }^{1, *}$, and S. Sommer ${ }^{2}$ \\ ${ }^{1}$ Sonderforschungsbereich 754, Christian-Albrechts-University Kiel, Climate-Biogeochemistry Interactions in the Tropical \\ Ocean, Kiel, Germany \\ ${ }^{2}$ GEOMAR, Helmholtz-Zentrum für Ozeanforschung Kiel, Wischhofstr. 1-3, 24148 Kiel, Germany \\ * present address: Geoteam Schaffer, Gärtnerstrasse 38, 70329 Stuttgart, Gemany
}

Correspondence to: N. Glock (nglock@geomar.de)

Received: 4 December 2012 - Published in Biogeosciences Discuss.: 12 December 2012

Revised: 29 May 2013 - Accepted: 10 June 2013 - Published: 15 July 2013

\begin{abstract}
The discovery that foraminifera are able to use nitrate instead of oxygen as an electron acceptor for respiration has challenged our understanding of nitrogen cycling in the ocean. It was thought before that only prokaryotes and some fungi are able to denitrify. Rate estimates of foraminiferal denitrification have been very sparse and limited to specific regions in the oceans, not comparing stations along a transect of a certain region. Here, we present estimates of benthic foraminiferal denitrification rates from six stations at intermediate water depths in and below the Peruvian oxygen minimum zone (OMZ). Foraminiferal denitrification rates were calculated from abundance and assemblage composition of the total living fauna in both surface and subsurface sediments, as well as from individual species specific denitrification rates. A comparison with total benthic denitrification rates as inferred by biogeochemical models revealed that benthic foraminifera probably account for the total denitrification in shelf sediments between 80 and $250 \mathrm{~m}$ water depth. The estimations also imply that foraminifera are still important denitrifiers in the centre of the OMZ around $320 \mathrm{~m}$ (29-50\% of the benthic denitrification), but play only a minor role at the lower OMZ boundary and below the $\mathrm{OMZ}$ between 465 and $700 \mathrm{~m}$ (2-6\% of total benthic denitrification). Furthermore, foraminiferal denitrification has been compared to the total benthic nitrate loss measured during benthic chamber experiments. The estimated foraminiferal denitrification rates contribute 2 to $46 \%$ to the total nitrate loss across a depth transect from 80 to $700 \mathrm{~m}$, respectively. Flux rate estimates range from 0.01 to $1.3 \mathrm{mmol} \mathrm{m}^{-2} \mathrm{~d}^{-1}$. Furthermore we show that the amount of nitrate stored in liv-
\end{abstract}

ing benthic foraminifera ( 3 to $3955 \mu \mathrm{mol} \mathrm{L}^{-1}$ ) can be higher by three orders of magnitude as compared to the ambient pore waters in near-surface sediments sustaining an important nitrate reservoir in Peruvian OMZ sediments. The substantial contribution of foraminiferal nitrate respiration to total benthic nitrate loss at the Peruvian margin, which is one of the main nitrate sink regions in the world ocean, underpins the importance of the previously underestimated role of benthic foraminifera in global biogeochemical cycles.

\section{Introduction}

Nitrate is a limiting nutrient in surface ocean primary productivity and takes a central role in marine biogeochemistry (Gruber, 2004; Arrigo, 2005; Lam et al., 2009). In the oceanic nitrogen cycle, $\mathrm{N}_{2}$ from the atmosphere becomes bioavailable by $\mathrm{N}_{2}$ fixation. The loss of nitrogen from the marine ecosystem to the atmosphere as $\mathrm{N}_{2}$ gas is dominated by two major pathways. One way is nitrate respiration in facultative anaerobic microorganisms which produce $\mathrm{N}_{2}$ from $\mathrm{NO}_{3}^{-}$(heterotrophic denitrification). The other process is anaerobic oxidation of ammonium (Anammox) by $\mathrm{NO}_{2}^{-}$, which yields $\mathrm{N}_{2}$ (van de Graaf et al., 1995; Thamdrup and Dalsgaard, 2002; Kuypers et al., 2003).

About 20 to $40 \%$ of the global nitrogen loss in the oceans is estimated to take place in oxygen minimum zones (OMZs), although these zones occupy only $0.1 \%$ of the global ocean volume (Gruber and Sarmiento, 1997; Gruber, 2004; Lam et al., 2009). Nitrate is usually depleted in 
near-surface waters due to utilisation by primary producers. Remineralisation of degraded organic matter produces $\mathrm{NH}_{4}^{+}$which is stepwise oxidized to $\mathrm{NO}_{3}^{-}$under aerobic conditions (nitrification). Thus, the $\mathrm{NO}_{3}^{-}$concentration usually increases with water depth. Denitrification also proceeds stepwise with a number of intermediate species involved $\left(\mathrm{NO}_{3}^{-} \rightarrow \mathrm{NO}_{2}^{-} \rightarrow \mathrm{NO} \rightarrow \mathrm{N}_{2} \mathrm{O} \rightarrow \mathrm{N}_{2}\right)$. Nevertheless, only the complete process with the final product $\mathrm{N}_{2}$ meets the strict definition of denitrification (Zumft, 1997; Lam et al., 2009).

Another concurring nitrate consuming process is dissimilatory nitrate reduction to ammonium (DNRA). It usually takes place under low-oxygen conditions. DNRA by sulfur bacteria (Thioploca and Beggiotoa) seems to be a major pathway of nitrate loss at the shelf and upper slope of the Peruvian OMZ between 78 and $259 \mathrm{~m}$ water depth, while denitrification is the major pathway at depths beyond $319-1005 \mathrm{~m}$ (Bohlen et al., 2011; Mosch et al., 2012).

Recent studies showed that several benthic foraminiferal species facultatively may change to nitrate respiration when dissolved oxygen becomes depleted in the water (RisgaardPetersen et al., 2006; Piña-Ochoa et al., 2010a). Four of the analysed foraminiferal species (all from Peruvian OMZ) denitrify to $\mathrm{N}_{2} \mathrm{O}$ rather to $\mathrm{N}_{2}$, implying that they might lack nitrous oxide reductase (Piña-Ochoa et al., 2010a). The contribution of foraminiferal denitrification to the total nitrate loss may range from $4 \%$ (Sagami Bay, Japan; Glud et al., 2009) to more than $70 \%$ (Bay of Biscay or Skagerrak; Piña-Ochoa et al., 2010a). Even if the contribution of foraminiferal denitrification is considered low like at the Sagami Bay study site, $\mathrm{NO}_{3}^{-}$stored in foraminiferal cells still comprised $\sim 80 \%$ of the total benthic nitrate pool. Results of Risgaard-Petersen et al. (2006) and Bernhard et al. (2012a) suggested that denitrification in Globobulimina pseudospinescens (Globobulimina turgida of authors), Bolivina argentea, Fursenkoina cornuta and Nonionella stella is not performed by prokaryotic symbionts. Even after treatment with antibiotics, B. argentea was still able to denitrify (Bernhard et al., 2012a). Nevertheless, denitrification in a "clade L" allogromid from the Santa Barbara Basin was most likely catalysed by endosymbionts (Bernhard et al., 2012b). Buliminella tenuata also hosts abundant endobionts (Bernhard et al., 2012a). Thus, denitrification in some species is performed by symbionts while other species denitrify on their own. Although this foraminiferal denitrification has not been traced to a specific cell organelle yet (Høgslund et al., 2008), there are indications that the pores in some foraminiferal species are involved in the denitrification process (Glock et al., 2011, 2012). The recent proof that benthic diatoms are able to respire nitrate via DNRA shows that foraminifera are not the only important group of marine eukaryotes with the ability of nitrate respiration (Kamp et al., 2011). Other eukaryotes with the ability of denitrification are two fungi, Fusarium oxysporum and Cylindrocarpon tonkinense (Shoun and Tanimoto, 1991; Usuda et al., 1995), and the eukaryotic protists Lox- odes (Finlay et al., 1983). Prokopenko et al. (2011) showed that denitrification in anoxic sediments is strongly supported by biological nitrate transport through cell-stored nitrate. They also estimated based on a data constrained model that at least $31 \%$ of the total $\mathrm{N}_{2}$ production in anoxic sediments is mediated by biologically transported nitrate.

In order to estimate the contribution of foraminiferal denitrification to the total benthic denitrification and the total benthic nitrate turnover in the Peruvian OMZ, we apply speciesspecific denitrification rates as documented in the literature to living benthic foraminiferal assemblages at six sampling stations. The results will emphasize the relevance of benthic foraminifera for the nitrogen budget at one of the most important nitrate sinks in the world ocean.

\section{Material and methods}

\subsection{Sampling procedure}

During R/V Meteor cruises M77/1 and M77/2 (October and November 2008), six sediment cores from the Peruvian OMZ were recovered with a video-guided multiple corer (MUC) for foraminiferal analyses in the present study (Fig. 1, Table 1). The coring tubes were of $100 \mathrm{~mm}$ inner diameter. Immediately after retrieval, one multicorer tube was brought to a cooling laboratory with a constant temperature of $4{ }^{\circ} \mathrm{C}$. Supernatant water of the core was carefully removed. The core was sliced in 2 or $5 \mathrm{~mm}$ intervals from 0 to $10 \mathrm{~mm}$, in $5 \mathrm{~mm}$ intervals from 10 to $40 \mathrm{~mm}$, and in $10 \mathrm{~mm}$ intervals from 40 to $50 \mathrm{~mm}$ sediment depth in order to resolve the microhabitat structure of endobenthic foraminifera (e.g. Corliss, 1985; Bernhard et al., 2003).The samples were filled in PVC bottles, stained and preserved with a solution of 2 gram rose bengal per liter of ethanol (Lutze and Altenbach, 1991; Schönfeld et al., 2012). Afterwards, the samples were transported and then stored at $4{ }^{\circ} \mathrm{C}$ at GEOMAR, Kiel, Germany. Staining with rose bengal is a valid method for the identification of the foraminiferal living fauna but might also overestimate its size: decaying protoplasm of foraminifera that have ceased their metabolic activity, and which is degrading slowly under anoxic conditions, can also be stained (Walker et al., 1974; Bernhard, 1988; Murray and Bowser, 2000; Bernhard, 2000; Schönfeld et al., 2012).

Additional cores were sampled for pore water chemistry at twelve locations (see Fig. A1 and Table A2 in the Appendix). To prevent contamination with atmospheric oxygen, these cores were either sliced under a protective Ar-atmosphere in a glove bag or rhizons were inserted into the sediment through small holes in the core tube and the pore water was directly sampled and filtrated through the rhizons into syringes and collected in PTFE bottles.

The sediment from the "glove bag cores" was pushed out of the tube, cut into $10 \mathrm{~mm}$ thick slices and transferred into centrifuge vials. The pore water was separated from 
Table 1. Sampling sites for foraminiferal studies. Bottom water oxygen concentrations $\left[\mathrm{O}_{2}\right]_{\mathrm{BW}}$ in italics are taken from Glock et al. (2011). All other $\left[\mathrm{O}_{2}\right]_{\mathrm{BW}}$ are derived from close by stations of the conductivity, temperature, depth (CTD) sensor. Note that the detection limit for the CTD oxygen sensor was $\sim 2 \mu \mathrm{mol} \mathrm{kg}^{-1}$.

\begin{tabular}{lcccc}
\hline Site & $\begin{array}{c}\text { Longitude } \\
(\mathrm{S})\end{array}$ & $\begin{array}{c}\text { Latitude } \\
(\mathrm{W})\end{array}$ & $\begin{array}{c}\text { Water } \\
\text { depth }(\mathrm{m})\end{array}$ & $\begin{array}{c}{\left[\mathrm{O}_{2}\right]_{\mathrm{BW}}} \\
\mu \mathrm{mol} \mathrm{kg}\end{array}$ \\
\hline M77/1-540/MUC-49 & $11^{\circ} 00.01^{\prime}$ & $77^{\circ} 47.40^{\prime}$ & 79 & 1.07 \\
M77/1-583/MUC-65 & $11^{\circ} 06.86^{\prime}$ & $78^{\circ} 03.06^{\prime}$ & 248 & 1.05 \\
M77/1-473/MUC-32 & $11^{\circ} 00.01^{\prime}$ & $78^{\circ} 09.94^{\prime}$ & 317 & 1.00 \\
M77-1-449/MUC-19 & $11^{\circ} 00.01^{\prime}$ & $78^{\circ} 09.97^{\prime}$ & 319 & 1.00 \\
M77/1-456/MUC-22 & $11^{\circ} 00.013^{\prime}$ & $78^{\circ} 19.23^{\prime}$ & 465 & 2.42 \\
M77/1-459/MUC-25 & $11^{\circ} 00.03^{\prime}$ & $78^{\circ} 35.60^{\prime}$ & 697 & 12.55 \\
\hline
\end{tabular}

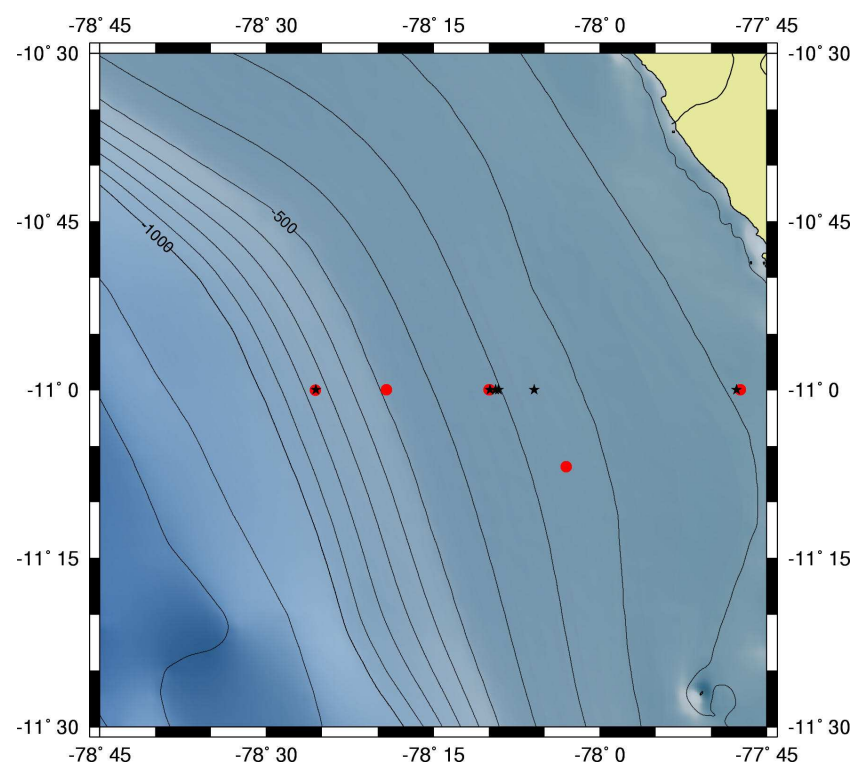

Fig. 1. Map of sampling sites. Red circles: foraminiferal studies and pore water profiles; black stars: lander sites for in situ flux data. Note that at the 79, 319 and $697 \mathrm{~m}$ sites, consistent datasets are available for foraminifera, pore water profiles and lander data (three lander and two foraminifera repetitions on different days for the $319 \mathrm{~m}$ site). At $248 \mathrm{~m}$ the MUC site for foraminiferal studies and pore water profiles is about $0^{\circ} 07^{\prime}$ south of the corresponding lander station.

sediments with a cooled centrifuge, filtrated with syringe filters $(0.2 \mathrm{~nm}$ cellulose-acetate filters $)$ under argon atmosphere and collected in PTFE bottles. Both methods were used to preserve the pore water from oxygen contamination.

At five of these locations, other cores were sampled for pore water nitrate with an additional method. These cores were cut into $10 \mathrm{~mm}$ thick slices. The pore water was squeezed out of the sediment with a pore water press, filtrated and collected into PTFE bottles. The advantage of this method is that also cell-stored nitrate is partly squeezed out of the cells. Comparing nitrate concentrations measured from these samples and centrifuged or rhizon-collected pore wa- ters, a rough estimate of the amount of cell-stored nitrate in the sample can be made.

\subsection{Foraminiferal studies}

The foraminiferal samples were washed through stacked sieves with mesh sizes of $2000 \mu \mathrm{m}$ and $63 \mu \mathrm{m}$. The $63-2000 \mu \mathrm{m}$ size fraction was dried at $50^{\circ} \mathrm{C}$ and weighed. The residues were subdivided with an Otto (1937) microsplitter until aliquots had a manageable size with a target value of at least 300 well-stained individuals that were considered as living at the time of sampling. Specimens were picked either dry or wet, sorted by species in Plummer cell slides, fixed with glue and counted (Mallon et al., 2012). For the complete faunal references, see Mallon (2012).

\subsection{Calculation of foraminiferal denitrification rates and foraminiferal nitrate storage}

The density of living foraminiferal specimens in the sediment under a certain area (ind $\mathrm{cm}^{-2}$; usually defined as standing stock) is referred here as foraminiferal abundance. The foraminiferal abundance was calculated for each species in the individual core slices and referred to the sample surface (ind $\mathrm{cm}^{-2}$ ). The abundances in each slice were integrated for the whole core studied, regardless of sampling depth. Thus, we tried to consider the entire living fauna despite habitat depth, including all microhabitats. The abundances were multiplied by the individual denitrification rates based on the values of Piña-Ochoa et al. (2010a) and RisgaardPetersen et al. (2006) for the investigated species. Unfortunately, since individual denitrification rates were not available for every species, two assumptions were made. For some species individual denitrification rates were adopted from other species of the same genus with similar ecological preferences. We applied average genus denitrification rates for these species (assumption A). Exceptionally high rates that have been reported for $B$. argentea and $F$. cornuta from the Santa Barbara Basin are not taken into account (Bernhard et al., 2012a). The individual denitrification rate for B. $a r$ gentea is $1976 \mathrm{pmol}_{\text {ind }}{ }^{-1} \mathrm{~d}^{-1}$. For other Bolivinidae from 
Table 2. Individual foraminiferal denitrification rates and nitrate storage for the different species used to calculate total benthic foraminiferal denitrification and nitrate storage at the different sampling sites. Bold numbers represent species where literature data was available for the distinct species. Numbers in italics were calculated using assumption A (mean values of other species from the same genus). Data are from Piña-Ochoa et al. (2010a) except for the denitrification rate of Nonionella stella (Risgaard-Petersen et al., 2006).

\begin{tabular}{lrr}
\hline Species & $\begin{array}{r}\text { Denitrification } \\
\left(\mathrm{pmol} \mathrm{ind}^{-1} \mathrm{~d}^{-1}\right)\end{array}$ & $\begin{array}{r}\text { Nitrate storage } \\
\left(\mathrm{pmol} \mathrm{ind}^{-1}\right) \pm \text { SEM }\end{array}$ \\
\hline Bolivina alata var. A & 124 & $\mathbf{6 1 5} \pm \mathbf{1 5 4}$ \\
Bolivina alata var. B & 124 & $\mathbf{6 1 5} \pm \mathbf{1 5 4}$ \\
Bolivina costata & 124 & $338 \pm 155$ \\
Bolivina interjuncta & 124 & $338 \pm 155$ \\
Bolivina (Loxostomum) boltovskoyi & 124 & $338 \pm 155$ \\
Bolivina (Loxostomum) salvadorensis & 124 & $338 \pm 155$ \\
Bolivina plicata & $\mathbf{7 9}$ & $\mathbf{4 7 8} \pm \mathbf{7 2}$ \\
Bolivina seminuda & $\mathbf{2 1 6}$ & $\mathbf{5 6 4} \pm \mathbf{1 3 5}$ \\
Bolivina spissa & 124 & $338 \pm 155$ \\
Cancris carmenensis & & $262877 \pm 4253$ \\
Cassidulina auka & & $182 \pm 145$ \\
Globobulimina pacifica & & $7462 \pm 2765$ \\
Nonionella stella & $\mathbf{1 8 6} \pm \mathbf{2 4}$ \\
Uvigerina auberiana & $\mathbf{8 4}$ & $1090 \pm 204$ \\
Uvigerina canariensis & 46 & $1090 \pm 204$ \\
Uvigerina peregrina & 46 & $\mathbf{3 3 2} \pm \mathbf{1 8 4}$ \\
Uvigerina striata & 46 & $1090 \pm 204$ \\
Valvulineria vilardeboana var. glabra & 46 & \\
\hline
\end{tabular}

the Peruvian OMZ with a similar test size, denitrification rates range from 79 to $216 \mathrm{pmol}_{\text {ind }^{-1}} \mathrm{~d}^{-1}$ (Piña-Ochoa et al., 2010a). The individual denitrification rates taken for calculations are reported in Table 2.

In the second assumption, $\mathrm{B}$, the proportions of species from genera with no available denitrification rates were added. The total denitrification rate of all other species at a sampling site was applied for this cumulative percentage of the species for which denitrification rates are not available. Thus, if $90 \%$ of all foraminifera belong to genera where denitrification rates are available, $10 \%$ is added to the results derived without assumption plus assumption A. The basic argument for this approach was the ecological consideration that in environments with a considerable faunal diversity and where one factor is dominating and limiting, in this case nitrate, it will affect all species (Murray, 2001). Thus, a single species will not outcompete all others by exceptionally high nitrate utilisation. Accounting for the higher uncertainty involved in assumption $\mathrm{B}$, the rates calculated following this approach were plotted and interpreted separately.

The concentration of foraminiferal cell-stored nitrate in the uppermost centimetres of the near-surface sediment was estimated by using the foraminiferal abundances. Abundances in this interval were multiplied by the nitrate content of the cytoplasm of the different species as reported by PiñaOchoa et al. (2010a). Only assumption A was used for the calculation of the cell-stored nitrate. The individual nitrate storage for the different species used for the calculations is given in Table 2.

\subsection{In situ flux measurements}

In situ fluxes were measured using the biogeochemical observatories BIGO and BIGO-T as described in detail by Sommer et al. (2009) at 6 sites traversing the Peruvian OMZ during Meteor cruise 77/1 and 77/2 in November and December 2008. These sites were distributed along a latitudinal depth transect at $11^{\circ} \mathrm{S}$ covering a water depth range of 85 to $1000 \mathrm{~m}$ and a horizontal distance of approximately 80 $\mathrm{km}$ (Table 5, Fig. 1). In this study, only the fluxes from 5 sampling sites will be reported where foraminiferal faunas were investigated. Along the transect, oxygen levels were $<2 \mu \mathrm{mol} \mathrm{L}{ }^{-1}$ down to a water depth of $\sim 500 \mathrm{~m}$. Below $500 \mathrm{~m}$, bottom water oxygen concentrations gradually increased to about $40 \mu \mathrm{M}$ at $1000 \mathrm{~m}$ (Sommer et al., 2010). In situ flux measurements at $595 \mathrm{~m}$ water depth were not conducted since the BIGO chambers did not fully penetrate the sediment because of chunks of hard substrate and phosphorite concretions. The BIGO observatories contained two circular flux chambers (internal diameter $28.8 \mathrm{~cm}$, area $651.4 \mathrm{~cm}^{2}$ ), herein referred to as chamber $1(\mathrm{C} 1)$ and chamber 2 (C2). BIGO-T is similar to BIGO but contained only one benthic chamber of the same size as those deployed in BIGO, which could be flushed intermittently during incubation. Two hours after the observatories were deployed on the sea floor, the chambers were slowly driven into the sediment. During this initial time period, the water inside the flux chamber was periodically replaced with ambient bottom water. After the chamber was fully driven into the sediment, 
the chamber water was again replaced with ambient bottom water to flush out solutes that might have been released from the sediment during chamber insertion. The water volume enclosed by the benthic chamber ranged from 8.8 to $18.5 \mathrm{~L}$.

To determine nitrate fluxes $\left(\mathrm{NO}_{3}^{-}\right), 4$ sequential water samples of $47 \mathrm{~mL}$ each were removed periodically with glass syringes from the incubation chambers. During the deployments of BIGO-T, a series of 4 water samples were taken before and after the chamber water was replaced. The syringes were connected to the chamber using $1 \mathrm{~m}$ long Vygon tubes with a dead volume of $6.9 \mathrm{~mL}$ filled with distilled water prior to deployment. An additional syringe water sampler (4 sequential samples) was used to monitor the ambient bottom water. The sampling ports for ambient seawater were positioned about $30-40 \mathrm{~cm}$ above the sediment-water interface. The flux measurements were conducted for different time periods, ranging from 17.8 to $33 \mathrm{~h}$ as defined by the time interval between the first and the last syringe water sampling. Immediately after retrieval of the observatories, the water samples were transferred to the onboard cool room $\left(4^{\circ} \mathrm{C}\right)$ for further sample processing and subsampling. The fluxes of the different nitrogen species were calculated from the linear increase or decrease of their concentrations with time. For the BIGO-T deployments two fluxes were calculated for each nitrogen species, one for the first series of water samples taken prior to the replacement of the chamber water, denoted as I1, and another one for the second series of water samples taken thereafter (I2). Negative nitrate flux rates from the lander measurements will be referred as nitrate loss hereafter.

\subsection{Pore water nitrate concentrations}

Nitrate concentrations in pore and bottom waters were measured onboard using a Metrohm 761 compact ionchromatograph equipped with a Methrom/Metrosep A SUPP5 anion-exchange column $(150 / 4.0 \mathrm{~mm})$ and solution of $\mathrm{Na}_{2} \mathrm{CO}_{3}(3.2 \mathrm{mM})$ with $\mathrm{NaHCO}_{3}(1.0 \mathrm{mM})$ as eluent. The IAPSO seawater standard was used for calibration. The method was described in detail by Grasshoff et al. (1999). Nitrate was measured with a detection limit of $1 \mu \mathrm{mol} \mathrm{L}{ }^{-1}$ and a relative error of $5 \%$.

\section{Results}

\subsection{Distribution of living benthic foraminifera along $11^{\circ} \mathrm{S}$ at the Peruvian $\mathrm{OMZ}$}

Foraminiferal assemblages in sediments of the centre of the Peruvian OMZ were characterized by low diversities and very high population densities (Mallon et al., 2012). Population densities in the top $5 \mathrm{~mm}$ of the sediments reached values of $1045 \mathrm{ind} \mathrm{cm}^{-3}$ (Appendix A). This is comparable to results from other OMZs (Phleger and Soutar, 1973, Baja California, Mexico; Gooday et al., 2000; den Dulk et al., 1998; Jannink et al., 1998; and Schumacher et al., 2007, for the
Arabian Sea OMZ). At $79 \mathrm{~m}$ the total benthic foraminiferal abundance was 344 ind $\mathrm{cm}^{-2}$. The highest abundances were found at $248 \mathrm{~m}$ water depth $\left(616 \mathrm{ind} \mathrm{cm}^{-2}\right)$. From the centre of the OMZ ( 317 and $319 \mathrm{~m}$ ) to the lower OMZ boundary $(465 \mathrm{~m})$, the abundances declined down from 496 to 61 ind $\mathrm{cm}^{-2}$. The lowest values were found below the OMZ $\left(697 \mathrm{~m}, 13\right.$ ind $\left.\mathrm{cm}^{-2}\right)$.

Except the station immediately below the OMZ at $697 \mathrm{~m}$, the dominating species were Bolivinidae $(70-95 \%$ of the foraminiferal abundance). At $79 \mathrm{~m}$ water depth the dominant species was Bolivina costata $(74 \%)$ followed by Nonionella stella (16\%) and Bolivina seminuda (5\%). Bolivina seminuda was dominant at $248 \mathrm{~m}(90 \%)$, while B. costata and Epistominella obesa were the second-ranked species (3\% each). In the stations in the centre of the OMZ (317 and $319 \mathrm{~m})$, B. seminuda was still the dominant species (67-70\%), followed by B. costata $(6-15 \%)$ and B. plicata (6-13\%). Cancris carmenensis was common at one of these stations $(6 \%)$. At the lower boundary of the permanent anoxic core of the OMZ ( $465 \mathrm{~m})$, the most abundant species were Bolivina interjuncta (44\%) and B. seminuda (20\%). Assemblages were much more diverse at the station below the OMZ core $(697 \mathrm{~m})$, where Uvigerina peregrina $(19 \%)$, B. spissa (17\%) and Cassidulina delicata (14\%) were frequent. It has to be emphasized that these figures differ from previously published data from surface sediments (Mallon et al., 2012) in that values reported in this paper always referred to the total benthic foraminiferal fauna including both surface and subsurface assemblages.

\subsection{Comparison of foraminiferal denitrification rates to total benthic denitrification rates and nitrate flux rates from lander measurements}

The percentages of species with known denitrification rates and of the species covered by assumption A and B at the different sampling sites are shown in Table 3. Using the composition of benthic foraminiferal assemblages, the benthic foraminiferal denitrification rates were calculated (Table 4). Note that only at the station immediately below the OMZ (697 m) did assumption B have a strong impact on the calculations (54\% of the species).

The calculated benthic foraminiferal denitrification rates for the different sampling sites are shown in Table 4. Foraminiferal denitrification showed a maximum of $1.32 \mathrm{mmol} \mathrm{m}^{-2} \mathrm{~d}^{-1}$ at $248 \mathrm{~m}$ (upper part of the OMZ) water depth and reached a minimum of $0.01 \mathrm{mmol} \mathrm{m}^{-2} \mathrm{~d}^{-1}$ below the $\mathrm{OMZ}$ at $697 \mathrm{~m}$, where the bottom water oxygen level was $12.6 \mu \mathrm{mol} \mathrm{L}^{-1}$ (Glock et al., 2011). Bohlen et al. (2011) used a dataset including pore water concentration profiles and in situ benthic fluxes of different nitrogen species to calculate rates of denitrification (divided in turnover rates from $\mathrm{NO}_{3}^{-}$to $\mathrm{NO}_{2}^{-}$, and $\mathrm{NO}_{2}^{-}$to $\mathrm{N}_{2}$ ), nitrification, anammox and DNRA. For our comparison to the benthic foraminiferal denitrification, we used the modelled denitrification rates from $\mathrm{NO}_{3}^{-}$to 
Table 3. Contribution of species with known denitrification rates and assumptions A and B in the calculations of benthic foraminiferal denitrification rates at the different sampling sites. The percentage of living individuals of the three subgroups of species (without assumption, assumption A, and assumption B) to the total foraminiferal abundance is shown. The column "individual denitrification rates" indicates species where literature data for the individual rates was available.

\begin{tabular}{lccc}
\hline Site & $\begin{array}{c}\text { Individual } \\
\text { denitrification } \\
\text { rates (\%) }\end{array}$ & $\begin{array}{c}\text { Estimate using } \\
\text { assumption A (\%) }\end{array}$ & $\begin{array}{c}\text { Estimate using } \\
\text { assumption B (\%) }\end{array}$ \\
\hline M77/1-540/MUC-49 & 21.1 & 73.9 & 5.0 \\
M77/1-583/MUC-65 & 90.3 & 3.4 & 6.3 \\
M77/1-473/MUC-32 & 80.0 & 15.9 & 4.1 \\
M77-1-449/MUC-19 & 76.1 & 7.5 & 16.4 \\
M77/1-456/MUC-22 & 22.3 & 57.7 & 21.0 \\
M77/1-459/MUC-25 & 0.1 & 45.6 & 54.4 \\
\hline
\end{tabular}

Table 4. Estimated total benthic foraminiferal denitrification rates and nitrate storage at the different sampling sites. The column "foraminiferal denitrification without assumption B" covers the foraminiferal denitrification for species where literature data for the individual rates was available plus the denitrification rates derived by assumption A. Also listed are foraminiferal abundances and pore water nitrate concentrations in the top centimetres of the sediments. The elevated pore water nitrate concentrations in samples from the pore water press most probably result from squashed foraminiferal as well as Thioploca and Beggiotoa cells. Errors of foraminiferal nitrate storage are based on the standard errors of the mean (SEM) from Piña-Ochoa et al. (2010a).

\begin{tabular}{|c|c|c|c|c|c|c|c|c|}
\hline Site & $\begin{array}{l}\text { Water } \\
\text { depth } \\
(\mathrm{m})\end{array}$ & $\begin{array}{l}\text { Foraminiferal } \\
\text { abundance } \\
\text { (ind } \mathrm{cm}^{-2} \text { ) }\end{array}$ & $\begin{array}{c}\text { Total } \\
\text { foraminiferal } \\
\text { denitrification } \\
\left(\mathrm{mmol} \mathrm{m}^{-2} \mathrm{~d}^{-1}\right)\end{array}$ & $\begin{array}{c}\text { Foraminiferal } \\
\text { denitrification } \\
\text { without } \\
\text { assumption } \mathrm{B} \\
\left(\mathrm{mmol} \mathrm{m}^{-2} \mathrm{~d}^{-1}\right)\end{array}$ & $\begin{array}{l}\text { Foraminiferal } \\
\text { denitrification } \\
\text { assumption } \mathrm{B} \\
\left(\mathrm{mmol} \mathrm{m}{ }^{-2} \mathrm{~d}^{-1}\right)\end{array}$ & $\begin{array}{l}\text { Foraminiferal } \\
\text { nitrate storage } \\
(\mu \mathrm{mol} \mathrm{L}-1)\end{array}$ & $\begin{array}{l}\text { Pore water nitrate } \\
\text { (rhizons or } \\
\text { glove bag) } \\
(\mu \mathrm{mol} \mathrm{L}-1)\end{array}$ & $\begin{array}{c}\text { Pore water } \\
\text { nitrate (press) } \\
(\mu \mathrm{mol} \mathrm{L}-1)\end{array}$ \\
\hline M77/1-540/MUC-49 & 79 & 343.7 & 0.42 & 0.40 & 0.02 & $47.6 \pm 16.1$ & 4.4 & 93.2 \\
\hline M77/1-583/MUC-65 & 248 & 616.2 & 1.32 & 1.23 & 0.09 & $435.5 \pm 78.0$ & - & - \\
\hline M77/1-473/MUC-32 & 317 & 522.5 & 0.96 & 0.92 & 0.04 & - & - & - \\
\hline M77-1-449/MUC-19 & 319 & 262.4 & 0.55 & 0.44 & 0.11 & $3955.4 \pm 91.9$ & 0.6 & 102.0 \\
\hline M77/1-456/MUC-22 & 465 & 61.3 & 0,09 & 0.07 & 0.02 & $383.1 \pm 13.6$ & 2.3 & - \\
\hline M77/1-459/MUC-25 & 697 & 12.7 & 0.013 & 0.006 & 0.007 & $2.6 \pm 1.2$ & 15.8 & - \\
\hline
\end{tabular}

$\mathrm{NO}_{2}^{-}$, hereafter referred to as total benthic denitrification. We chose this rate instead of the turnover rate from $\mathrm{NO}_{2}^{-}$to $\mathrm{N}_{2}$ because it reflects the decomposition of nitrate by denitrification, and foraminifera are known to store nitrate for nitrate respiration (not nitrite). Since no total benthic denitrification rate was available for the $465 \mathrm{~m}$ site, we interpolated it from the the rates of the two closest sites (Bohlen et al., 2011).

The benthic foraminiferal denitrification was compared to the total benthic denitrification at different water depths (Fig. 2a and b). The comparison revealed that foraminiferal denitrification almost entirely covered the total benthic denitrification at the shallow stations in the upper OMZ. At the $79 \mathrm{~m}$ station, the estimated foraminiferal denitrification exceeded the total benthic denitrification as estimated from the models by $\sim 19 \%$. This proportion abruptly decreased with water depth. While in the centre of the OMZ (317 and 319 m) foraminifera still contribute about $29-50 \%$ to the total benthic denitrification, their contribution diminished to about $2-6 \%$ at the lower boundary and below the core of the OMZ (465-697 m).

The foraminiferal denitrification rates were compared with the nitrate loss rates as calculated from nitrate concentrations in the benthic chamber experiments (Table 5) in order to assess the demand of foraminiferal denitrification with reference to the total benthic nitrate uptake (Fig. 3a and b). Nitrate uptake rates were particularly low at the $85 \mathrm{~m}$ lander station $\left(0.9 \mathrm{mmol} \mathrm{m}^{-2} \mathrm{~d}^{-1}\right)$, coinciding with low pore water nitrate concentrations in the uppermost sediment. At water depths between 260 and $300 \mathrm{~m}$ (well within the OMZ), nitrate uptake was high ranging from 2.2 to $3.8 \mathrm{mmol} \mathrm{m}^{-2} \mathrm{~d}^{-1}$. At $695 \mathrm{~m}$ (below the permanent anoxic OMZ core) nitrate uptake declined. The demand of foraminiferal denitrification was constrained to $46 \%$ of the total benthic nitrate uptake at $79 \mathrm{~m}$. The consumption by foraminiferal denitrification was $39 \%$ at $248 \mathrm{~m}$ water depth, ranged between $36 \%$ and $18 \%$ in the centre of the OMZ, and was of the order of $\sim 2 \%$ at $697 \mathrm{~m}$ below the OMZ. The excess benthic nitrate uptake accounts for DNRA by sulfur bacteria and for anammox processes (Bohlen et al., 2011). 
Table 5. Benthic stations where in situ fluxes of nitrate loss (negative nitrate fluxes) were determined. The notations $\mathrm{C} 1$ and $\mathrm{C} 2$ refer to chambers 1 and 2, respectively. All stations lie on the latitudinal transect at $11^{\circ} \mathrm{S}$. $T_{\text {inc. }}$ denotes the duration of the chamber flux measurements. Negative and positive fluxes indicate uptake and release from the seabed, respectively. During the flux measurements of BIGO-T, the chamber water was replaced once with ambient seawater halfway through the incubation period. For these deployments, I1 refers to the time interval after driving the chamber into the sediment, $\mathrm{I} 2$ refers to the time interval after the chamber water was replaced. Also listed are the coinciding MUC stations for the foraminiferal studies. Italics indicate that the multicorer sample for the foraminiferal studies has been taken at a close by site at the same water depth, which is $\sim 0^{\circ} 07^{\prime}$ south of the lander station.

\begin{tabular}{|c|c|c|c|c|c|c|}
\hline Site & $\begin{array}{l}\text { Chamber/ } \\
\text { interval }\end{array}$ & $\begin{array}{c}\text { Water } \\
\text { depth }(\mathrm{m})\end{array}$ & $\begin{array}{l}\text { Position } \\
\text { (long.) W }\end{array}$ & $\begin{array}{c}T_{\text {inc. }} \\
\text { (h) }\end{array}$ & $\begin{array}{c}\mathrm{NO}_{3}^{-} \text {loss } \\
\left(\mathrm{mmol} \mathrm{m}^{-2} \mathrm{~d}^{-1}\right)\end{array}$ & $\begin{array}{c}\text { Coinciding with MUC } \\
\text { station }\end{array}$ \\
\hline \multirow{2}{*}{ M77/1-540/BIGO-5 } & $\mathrm{C} 1$ & 85 & $77^{\circ} 47.72^{\prime}$ & 18.0 & 0.9 & M77/1-540/MUC-49 \\
\hline & $\mathrm{C} 2$ & & & & - & \\
\hline \multirow[t]{2}{*}{ M77/1-583/BIGO-T6 } & I1 & 259 & $78^{\circ} 05.91^{\prime}$ & 19.4 & 3.8 & $M 77 / 1-583 / M U C-65$ \\
\hline & $\mathrm{I} 2$ & & & & 3.0 & \\
\hline \multirow[t]{2}{*}{ M77-1-566/BIGO-T4 } & I1 & 309 & $78^{\circ} 09.13^{\prime}$ & 20.7 & 2.5 & \\
\hline & $\mathrm{I} 2$ & & & & 2.7 & \\
\hline \multirow[t]{2}{*}{ M77/1-473/BIGO-1 } & $\mathrm{C} 1$ & 315 & $78^{\circ} 09.92^{\prime}$ & 17.8 & 3.2 & M77-1-449/MUC-19 \\
\hline & $\mathrm{C} 2$ & & & & 3.1 & \\
\hline \multirow[t]{2}{*}{ M77/1-586/BIGO-T5 } & I1 & 316 & $78^{\circ} 09.40^{\prime}$ & 12.7 & 2.2 & M77/1-473/MUC-32 \\
\hline & $\mathrm{I} 2$ & & & & 3.2 & \\
\hline \multirow[t]{2}{*}{ M77/1-456/BIGO 2} & $\mathrm{C} 1$ & 695 & $78^{\circ} 25.55^{\prime}$ & 18.1 & 0.7 & M77/1-459/MUC-25 \\
\hline & $\mathrm{C} 2$ & & & & 0.6 & \\
\hline
\end{tabular}
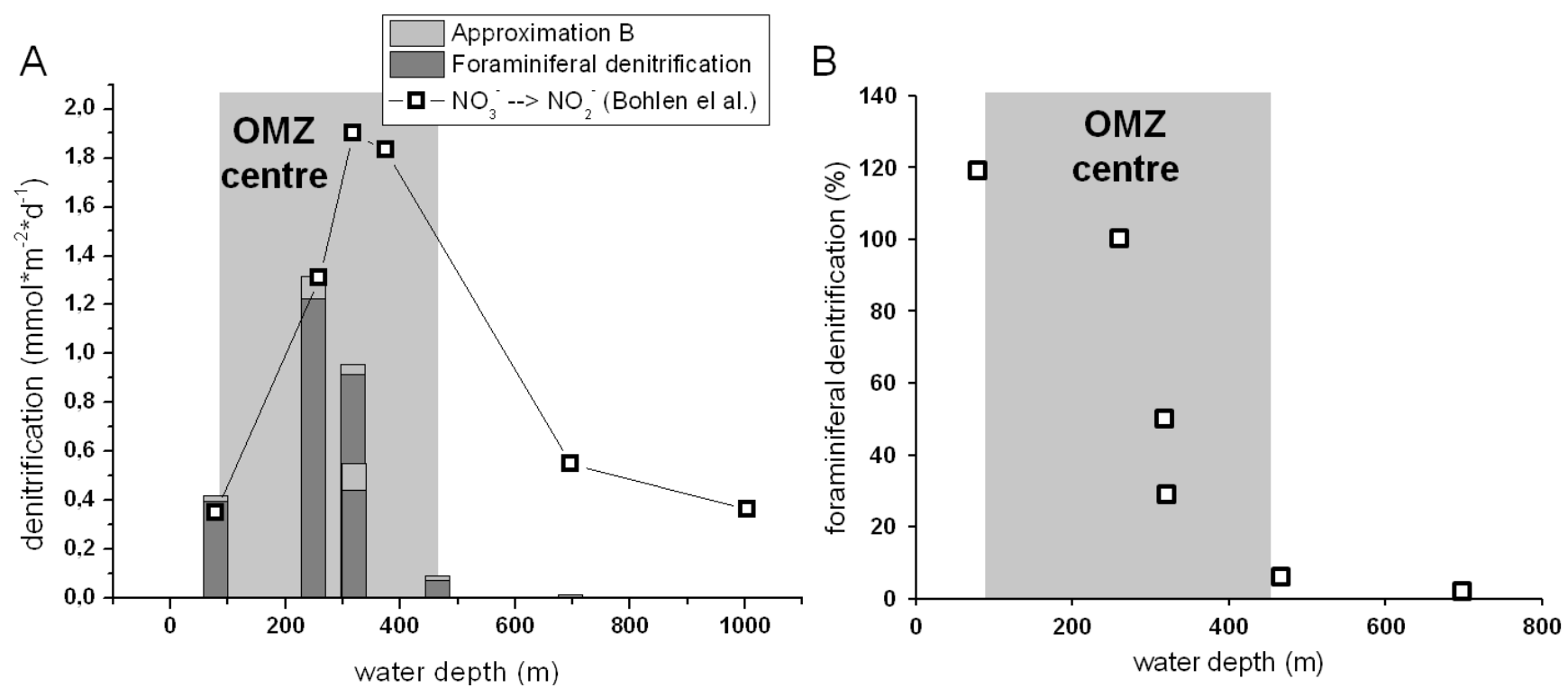

Fig. 2. (A) Comparison of benthic foraminiferal denitrification rates and modelled turnover rates from $\mathrm{NO}_{3}^{-}$to $\mathrm{NO}_{2}^{-}$(Bohlen et al., 2011), both plotted against water depth. (B) Percentage of the contribution of foraminiferal denitrification to the total benthic $\mathrm{NO}_{3}^{-}$loss due to denitrification.

\subsection{Foraminiferal nitrate storage and pore water nitrate concentrations}

The total amount of nitrate stored in foraminiferal cytoplasm in the $0-1 \mathrm{~cm}$ depth sediment was compared with nitrate concentrations in the ambient pore water (Table 4). The pore water nitrate concentrations from glove bag or rhizon samples from locations where foraminiferal data was also avail- able ranged from 0.6 to $4.4 \mu \mathrm{mol} \mathrm{L}-1$ at the upper and lower OMZ boundaries and in the centre of the OMZ (79-465 m), and to $15.8 \mu \mathrm{mol} \mathrm{L}^{-1}$ below the OMZ $(697 \mathrm{~m})$. The nitrate concentrations obtained from pore water press samples at the $79 \mathrm{~m}$ and $319 \mathrm{~m}$ stations were higher by an order of magnitude (Table 4). The calculated foraminiferal nitrate storage ranged from $47.6 \mu \mathrm{mol} \mathrm{L}^{-1}$ at the upper OMZ boundary to $3955.4 \mu \mathrm{mol} \mathrm{L}^{-1}$ in the centre of the OMZ, and decreased 

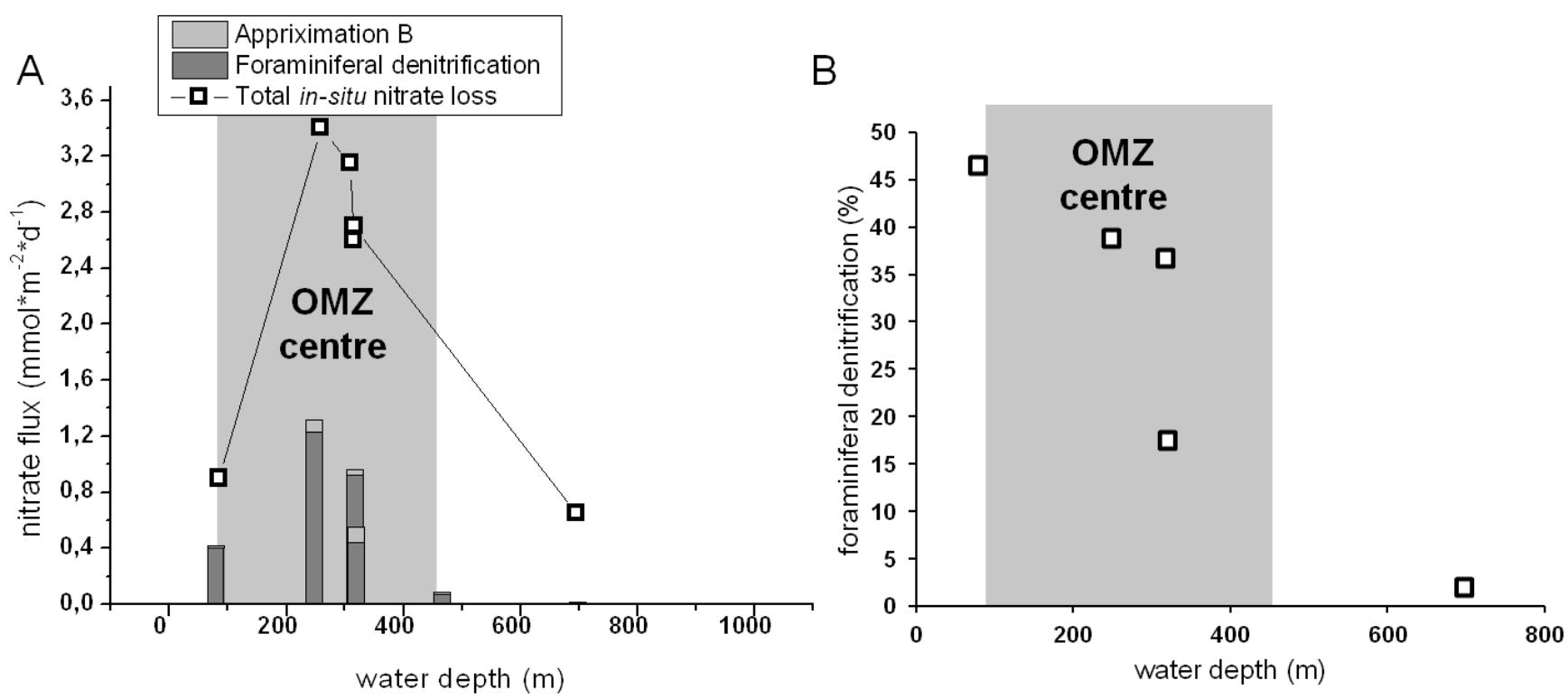

Fig. 3. (A) Comparison of benthic foraminiferal denitrification rates to the total in situ benthic $\mathrm{NO}_{3}^{-}$loss measured in the lander chambers, both plotted against water depth. (B) Percentage of the contribution of foraminiferal denitrification to the total in situ benthic $\mathrm{NO}_{3}^{-}$loss.

again to $383.1 \mu \mathrm{mol} \mathrm{L}{ }^{-1}$ at the lower boundary of the OMZ. Below the OMZ at $697 \mathrm{~m}$, the calculated foraminiferal nitrate storage was relatively low with $2.6 \mu \mathrm{mol} \mathrm{L}{ }^{-1}$. The complete pore water nitrate profiles are shown in the Fig. A2 in the Appendix.

\section{Discussion}

\subsection{Evaluation of study limitations in respect to assumptions $A$ and $B$}

From 79 to $465 \mathrm{~m}$ water depth, Bolivinidae are dominating the benthic foraminiferal assemblages. In this depth interval, Bolivina species account for 70-95\% of the total foraminiferal fauna comprising surface and subsurface assemblages. Below the OMZ at $697 \mathrm{~m}$, Bolivinidae account for approximately $25 \%$ of the total standing stock only. PiñaOchoa et al. (2010a) and Bernhard et al. (2012a) showed that 4 out of 4 analysed Bolivinidae are able to denitrify including two species from the Peruvian OMZ (B. seminuda and $B$. plicata). Bolivina seminuda is, with $67-90 \%$, the dominant species in the centre of the Peruvian OMZ at 248-319m, where $B$. plicata is also common. At these locations the two assumptions made for the calculations play only a minor role. At the upper boundary of the OMZ (79 m), the foraminiferal assemblages are dominated by $B$. costata $(74 \%)$, while at the lower boundary $(465 \mathrm{~m}) B$. interjuncta $(44 \%)$ and $B$. seminuda $(20 \%)$ are the dominating species. Measured denitrification rates were reported for B. seminuda and B. plicata (Piña-Ochoa et al., 2010a; Bernhard et al., 2012a), while denitrification rates for $B$. costata and B. interjuncta are not available. As these species are able to survive under anoxic conditions, it is reasonable to assume that they also can use an electron acceptor different from oxygen for their metabolism. Nitrate appears to be a likely source, because 11 out of 12 benthic foraminiferal species including 4 different Bolivinidae were proven to denitrify (RisgaardPetersen et al., 2006; Piña-Ochoa et al., 2010a; Bernhard et al., 2012a). The emerging fact that foraminiferal denitrification is widespread in general further supports our assumptions. Nevertheless, assumption A, which infers average values for non-designated species from the same genus, has a strong influence on the calculation. The denitrification estimate for the location at $697 \mathrm{~m}$ below the OMZ contains the highest uncertainty. About $54 \%$ of the species found at this station are from genera for which no denitrification data are available. Therefore, assumption B exerted a strong influence on the calculations. However, the population density and thus the calculated denitrification rate is comparatively low at this location. Even if we assume an error of the same magnitude as above, $50 \%$ for the denitrification estimate, there would be still an obvious difference to denitrification estimates at stations within the OMZ.

It has to be emphasized that despite the high contribution of foraminifera to total benthic denitrification at the shallower sites, our estimates only consider near-surface sediments up to $\sim 50 \mathrm{~mm}$ depth. For example, our data for station M77/1 583-MUC-32 (317 m) might underestimate foraminiferal denitrification because the core has just been sampled to $5 \mathrm{~mm}$ sediment depth. Nevertheless, a comparison to station 449-MUC-19 (essentially the same station 
sampled on a different day) shows that $\sim 90 \%$ of the living fauna can be found in the top $5 \mathrm{~mm}$ of this site.

\subsection{The role of benthic foraminiferal denitrification along the Peruvian OMZ}

Despite the novel pathway of nitrogen loss due to foraminiferal denitrification, so far the contribution of foraminiferal denitrification to the total benthic $\mathrm{N}_{2}$ production has only been measured for a single sampling site at $1450 \mathrm{~m}$ water depth at Sagami Bay, Japan (Glud et al., 2009). The data reveal that the contribution of foraminiferal denitrification to the overall budget $(4 \%)$ plays only a minor role at this site. In addition, the benthic foraminiferal abundance is rather low with only $12 \mathrm{ind} \mathrm{cm}^{-2}$ (size fraction $>125 \mu \mathrm{m}$ ) as compared to the OMZ off Peru (616 ind $\mathrm{cm}^{-2}$ ), although the different size fractions used for the foraminiferal studies might complicate the comparison of the abundances. Bottom water oxygen concentration was $>55 \mu \mathrm{mol} \mathrm{L}^{-1}$ in Sagami Bay and oxygen penetrated $\sim 3.0-12.4 \mathrm{~mm}$ into the sediments (Glud et al., 2009). Therefore, foraminifera might not necessarily depend on nitrate respiration in Sagami Bay. Off Peru, bottom water oxygen may fall below $0.02 \mu \mathrm{mol} \mathrm{kg}-1$ indicating essentially anoxic conditions for both bottom waters and subsurface sediments (Revsbech et al., 2009; Thamdrup et al., 2012). In the Peruvian OMZ, in particular where benthic foraminifera reach abundances of $616 \mathrm{ind} \mathrm{cm}^{-2}$ and are influenced by anoxic bottom waters, denitrification offers a survival strategy reflected by relatively high denitrification rates. Periodical oxygen intrusions due to coastal trapped waves are known for the water column and bottom waters at the upper boundary of the OMZ (Guitierrez et al., 2008), but the centre of the OMZ essentially stays anoxic and usually is not influenced by oxygen intrusions (Noffke et al., 2012). Oxygen concentrations of the pore waters are even more depleted.

It has been suggested that benthic foraminifera were responsible for $\sim 70 \%$ of the total denitrification in several regions (Piña-Ochoa et al., 2010a). Our estimates confirm this assumption and reveal that even the entire denitrification might be dominated by benthic foraminifera in sediments of the shallow part of the Peruvian OMZ at depths between 79 and $248 \mathrm{~m}$ water depth. At $79 \mathrm{~m}$, the estimated foraminiferal denitrification rate tends to be even higher than the total benthic denitrification as inferred by a biogeochemical model (Bohlen et al., 2011). Bolivina costata was the dominant species at this station. The individual denitrification rate for this species is yet unknown and has been obtained by using assumption A. Hence, foraminiferal denitrification could be overestimated in our calculations at this site.

Denitrification is not the main process of nitrate loss between 79 and $248 \mathrm{~m}$ water depths off Peru. Dissimilatory nitrate reduction to ammonium by sulfur-oxidizing bacteria plays an important role, as indicated by high ammonium flux rates inferred from benthic incubation experiments and by the widespread occurrence of bacterial mats (Beggiotoa) on the sea floor, as seen from video seabed surveys (Bohlen et al., 2011; Mosch et al., 2012). Total nitrate flux rates may reach $3.8 \mathrm{mmol} \mathrm{m}^{-2} \mathrm{~d}^{-1}$ at these sites, and maximum foraminiferal denitrification was estimated to $1.3 \mathrm{mmol} \mathrm{m}^{-2} \mathrm{~d}^{-1}$ at $248 \mathrm{~m}$; thus foraminifera account for $\sim 38-50 \%$ of the total benthic nitrate loss in the depth zone of Beggiotoa mats. These figures indicate that foraminiferal denitrification at the Peruvian OMZ is one of the highest ever estimated in the world ocean. Higher foraminiferal denitrification rates of $3.0 \mathrm{mmol} \mathrm{m}^{-2} \mathrm{~d}^{-1}$ were only estimated for the Santa Barbara Basin, where they accounted for $67 \%$ of the total benthic denitrification (Bernhard et al., 2012a). However, these values may be explained by the occurrence of $B$. argentea and F. cornuta in the Santa Barbara Basin with high population densities (e.g. Uchio, 1960; Bernhard and Reimers, 1991). These species showed individual denitrification rates of 1976 and $1386 \mathrm{pmol} \mathrm{ind}^{-1} \mathrm{~d}^{-1}$, by far the highest denitrification rates that were ever reported (Bernhard et al., 2012a). Only the denitrification rate of Globobulimina turgida was of a similar magnitude with $565 \mathrm{pmol}_{\text {ind }}^{-1} \mathrm{~d}^{-1}$ (Risgaard-Petersen et al., 2006). This species was not found in the living assemblages off Peru. It is common in the Atlantic Ocean, in particular under the upwelling off NW Africa and Namibia (Caralp et al., 1970; Lutze, 1980; Haake, 1980; Timm, 1992; Schmiedl et al., 1997; Heinz et al., 2004). Due to its infaunal lifestyle, Globobulimina turgida is rarely found living in surface sediment samples. Despite the possible high contribution of Globobulimina turgida, estimates of benthic foraminiferal denitrification were comparatively low in other regions and ranged from $0.07 \mathrm{mmol} \mathrm{m}^{-2} \mathrm{~d}^{-1}$ in the Tagus prodelta off Lisbon to $0.72 \mathrm{mmol} \mathrm{m}^{-2} \mathrm{~d}^{-1}$ in the Skagerrak (Piña-Ochoa et al., 2010a).

At the 317 and $319 \mathrm{~m}$ stations in the centre of the Peruvian OMZ, foraminifera still cover $30-50 \%$ of the total benthic denitrification modelled by Bohlen et al. (2011). This corresponds to $18-41 \%$ of the total nitrate loss as measured in benthic chambers, since ammonia from DNRA plays a less important role at these sampling sites. In fact, seafloor observations showed that bacterial mats were scattered and more threadlike in these water depths instead of extensive patchy occurrences at the upper OMZ boundary (Mosch et al., 2012). Since foraminifera were not the quantitative denitrifiers in the centre of the OMZ, prokaryotic denitrification must become more important in these habitats. Denitrifying bacteria are probably also the dominant denitrifiers at the deeper stations ( $465 \mathrm{~m}$ and $697 \mathrm{~m}$ ). Unfortunately, no lander measurements or model data were available for the $465 \mathrm{~m}$ site at the lower OMZ boundary. If the calculated foraminiferal denitrification is compared to the total benthic denitrification as interpolated from the two closest sites where model data were available (Bohlen et al., 2011), foraminifera only account for $5 \%$ to the total benthic denitrification.

Below the OMZ at $697 \mathrm{~m}$, foraminifera play only a minor role in benthic nitrate loss and account for $\sim 2 \%$ of 
the total nitrate budget. Contribution to benthic nitrate loss and foraminiferal abundances $\left(13\right.$ ind $\left.\mathrm{cm}^{-2}\right)$ were comparable to those at Sagami Bay (Glud et al., 2009). A direct and more detailed comparison is impeded by largely different environmental settings and a different species composition of foraminiferal assemblages off Japan (Kitazato, 1994; Ohga and Kitazato, 1997).

The fact that foraminiferal denitrification might have an impact on the benthic nitrogen cycle larger than previously thought is challenging. Piña-Ochoa et al. (2010a) already stated that measurements on marine denitrification that rely on ${ }^{15} \mathrm{~N}$ tracer additions (Cabrita and Brotas, 2000; Graco et al., 2001; Rysgaard et al., 2001) or on modelling of nitrate pore water profiles might underestimate the true total rate of denitrification, because denitrification in intracellular nitrate pools is not considered (Høgslund et al., 2008). Different incubation methods, in particular measuring the decrease of nitrate in the culture vessel fill or the increase of the $\mathrm{N}_{2} / \mathrm{Ar}$ ratio in the gas phase that percolates the incubation chambers might be likely to record foraminiferal denitrification at both species and assemblage levels and with more realistic values (Høgslund et al., 2008; Piña-Ochoa et al., 2010a).

\subsection{The role of benthic foraminifera in the sedimentary nitrate reservoir}

The concentration of nitrate in foraminiferal cells can be highly elevated as compared to levels in the ambient pore waters (Risgaard-Petersen et al., 2006; Høgslund et al., 2008; Piña-Ochoa et al., 2010a, b; Bernhard et al., 2012a, b). Even in habitats where the contribution of foraminiferal denitrification to the total benthic nitrate uptake is relatively low, foraminifera may contain the highest proportion of benthic nitrate (Glud et al., 2009). Our calculations revealed that nitrate concentrations in foraminiferal cytoplasm can be more than three orders of magnitude higher when compared to the levels in the adjacent pore waters. Especially species like Cancris carmenensis, having a large biomass and being able to store high amounts of nitrate, make foraminifera in the Peruvian OMZ an important sedimentary nitrate reservoir. Piña-Ochoa et al. (2010a) report very high nitrate concentrations $\left(0.26 \mu \mathrm{mol} \mathrm{cell}^{-1}\right)$ for Cancris inflatus, which is probably a synonym of Cancris carmenensis from the Peruvian OMZ. The foraminiferal nitrate storage shows high variability even within the same species. The SEMs of nitrate stored in 49 species reported by Piña-Ochoa et al. (2010a) varied from $2 \%$ to (in a single case) $179 \%$, with an average of $40 \%$. The uncertainties we assume for our estimations based on the SEMs documented for the species we used can be found in Table 4 (ranging from 2 to $46 \%$ ).

Pore water nitrate concentrations in two samples taken with a pore water press at 79 and $319 \mathrm{~m}$ were elevated by two orders of magnitude as compared to corresponding samples taken in a glove bag or with rhizons. It is conceivable that released intracellular nitrate may account for this differ- ence. Some amount of cell-stored nitrate could be squeezed out of squashed foraminiferal and Thioploca or Beggiotoa cells which were also common in these habitats (Mosch et al., 2012). The spatial extent of the bacterial mats is higher at the shallower shelf station $(79 \mathrm{~m})$, and the mats are rather threadlike at $319 \mathrm{~m}$ (Mosch et al., 2012), while the foraminiferal abundance is much higher at $319 \mathrm{~m}$. Since the pore water nitrate concentration from the pore water press is much lower at the $79 \mathrm{~m}$ site than at the $319 \mathrm{~m}$ site, it is reasonable to assume that some amount of the nitrate has been squeezed out of foraminiferal cells. The pressure inside the press is not isostatic but directed, and thus not comparable with the hydrostatic pressure in the habitat of the foraminifera. An external pressure is exerted on top of the sediment sample. Since the pore water is allowed to leave the system, the sediment is intensely compacted and physical properties are severely altered. Even though the exact mechanism of nitrate release from foraminiferal or bacterial cells during pore water extraction is not yet constrained, so-called "artificial subsurface nitrate peaks" in pore water profiles, as found in the Santa Barbara Basin (Bernhard and Reimers, 1991; Reimers et al., 1996, Bernhard et al., 2012a) and also in the Peruvian OMZ (see Fig. A2 in the Appendix; examples: 78 m, 319 m, $465 \mathrm{~m}, 512 \mathrm{~m}, 697 \mathrm{~m}$ ), are considered to originate from the cytoplasm of benthic organisms, most likely with an important contribution by foraminifera.

\section{Conclusions}

Our data highlights the importance of foraminiferal denitrification in one of the major regions of nitrate loss of the world ocean, the Peruvian OMZ, and that there are strong variations in the rate of foraminiferal denitrification even on a regional scale. In the shallow part of the Peruvian OMZ at $79 \mathrm{~m}$ and $248 \mathrm{~m}$ water depth, most likely the entire benthic denitrification is performed by foraminifera. In the centre of the OMZ at $300 \mathrm{~m}$ water depth, foraminifera still contribute $\sim 29-50 \%$ to the total benthic denitrification, while they play only a minor role $(\sim 2-6 \%)$ at the lower boundary and below the permanent anoxic centre of the OMZ from 465 to $697 \mathrm{~m}$ depth. Foraminiferal denitrification rates at our sampling locations reached up to $1.31 \mathrm{mmol} \mathrm{m}^{-2} \mathrm{~d}^{-1}$ and thus were among the highest ever estimated. Furthermore, nitrate stored in benthic foraminiferal cells contributes significantly to the benthic nitrate reservoir in this region. However, data on nitrate respiration rates and the knowledge of individual storage capacities of more species are required in order to better constrain the contribution of foraminifera to the nitrate budget of the world ocean. 


\section{Appendix}

Table A1. Population densities and abundances of living benthic foraminifera as calculated from census data of Mallon (2012). For complete faunal references, see also Mallon (2012).

\begin{tabular}{|c|c|c|c|c|c|c|c|c|c|c|c|c|c|}
\hline \multicolumn{14}{|l|}{ M77-1 540-MUC-49 } \\
\hline \multirow[b]{2}{*}{ Living specimens $\mathrm{cm}^{-2}$} & \multirow[b]{2}{*}{$0-2$} & \multirow[b]{2}{*}{$2-4$} & \multirow[b]{2}{*}{$4-7$} & \multirow[b]{2}{*}{$7-10$} & \multicolumn{3}{|c|}{ Sediment depth (mm) } & \multirow[b]{2}{*}{$25-30$} & \multirow[b]{2}{*}{$30-35$} & \multirow[b]{2}{*}{$35-40$} & \multirow[b]{2}{*}{$40-50$} & \multirow[b]{2}{*}{ Total } & \multirow[b]{2}{*}{$\%$} \\
\hline & & & & & $10-15$ & $15-20$ & $20-25$ & & & & & & \\
\hline Bolivina costata & 0.07 & 40.39 & 34.06 & 2.77 & 2.19 & 54.96 & 11.45 & 2.21 & 0.93 & 47.97 & 56.95 & 253.95 & 73.90 \\
\hline Bolivina seminuda & 0.02 & 7.92 & 5.33 & 0.15 & 0.12 & 0.44 & 0.05 & 0.06 & 0 & 2.15 & 0 & 16.24 & 4.73 \\
\hline Bulimina pupoides & 0.02 & 0 & 0.29 & 0 & 0 & 0.15 & 0.11 & 0.11 & 0.04 & 0.52 & 5.3 & 6.54 & 1.90 \\
\hline Buliminella elegantissima varlimbosa & 0 & 0.53 & 0.29 & 0.02 & 0.03 & 0 & 0.02 & 0 & 0 & 0 & 0 & 0.89 & 0.26 \\
\hline Buliminella elegantissima var. tenuis & 0 & 0 & 0.07 & 0 & 0 & 0 & 0 & 0 & 0 & 0 & 0 & 0.07 & 0.02 \\
\hline Epistominella exigua & 0 & 0.26 & 0 & 0 & 0 & 0 & 0 & 0 & 0 & 0 & 0 & 0.26 & 0.08 \\
\hline Fursenkoina fusiformis & 0.18 & 5.28 & 0 & 0.15 & 0.06 & 0 & 0.07 & 0.02 & 0.06 & 0 & 0 & 5.82 & 1.69 \\
\hline Nonionella stella & 0.27 & 44.62 & 8.78 & 0.95 & 0 & 0.73 & 0.14 & 0.08 & 0.08 & 0.07 & 0.55 & 56.27 & 16.37 \\
\hline Pulvinulinella subperuviana & 0 & 0 & 0.14 & 0 & 0.03 & 0 & 0.18 & 0.04 & 0.03 & 0 & 0.05 & 0.47 & 0.14 \\
\hline Virgulina texturata & 0.04 & 2.64 & 0.5 & 0 & 0 & 0 & 0 & 0.01 & 0 & 0 & 0 & 3.19 & 0.93 \\
\hline Loxostomum limbatum & 0 & 0 & 0 & 0 & 0 & 0 & 0.02 & 0 & 0.01 & 0 & 0 & 0.03 & 0.01 \\
\hline Total abundance [ind $\mathrm{cm}^{-2}$ ] & 0.6 & 101.64 & 49.46 & 4.03 & 2.42 & 56.26 & 12.04 & 2.51 & 1.15 & 50.7 & 62.85 & 343.66 & \\
\hline Number of counted specimens & 27 & 385 & 687 & 193 & 373 & 388 & 668 & 359 & 148 & 747 & 1259 & & \\
\hline Sample volume $\left[\mathrm{cm}^{3}\right]$ & 7.83 & 12.1 & 32.7 & 28.5 & 81.3 & 56.13 & 55.13 & 74.13 & 45.6 & 60.9 & 84.1 & & \\
\hline Split & 1 & 0.0625 & 0.125 & 0.5 & 1 & 0.0625 & 0.5 & 1 & 1 & 0.125 & 0.25 & & \\
\hline Population density [ind $\mathrm{cm}^{-3}$ ] & 3.4 & 509.1 & 168.1 & 13.5 & 4.6 & 110.6 & 24.2 & 4.8 & 3.2 & 98.1 & 59.9 & & \\
\hline
\end{tabular}

Table A1. Continued.

\begin{tabular}{|c|c|c|c|c|c|c|c|}
\hline \multicolumn{8}{|l|}{ M77-1 456-MUC-22 } \\
\hline \multirow[b]{2}{*}{ Living specimens $\mathrm{cm}^{-2}$} & \multicolumn{5}{|c|}{ Sediment depth (mm) } & \multirow[b]{2}{*}{ Total } & \multirow[b]{2}{*}{$\%$} \\
\hline & $0-2$ & $2-4$ & 4-6 & $6-8$ & $8-10$ & & \\
\hline Ammodiscus insertus & 0 & 0 & 0.04 & 0 & 0 & 0.04 & 0.07 \\
\hline Angulogerina carinata & 0.18 & 0.53 & 0.04 & 0.02 & 0 & 0.77 & 1.26 \\
\hline Bathysiphon sp. & 0 & 0 & 0.13 & 0 & 0 & 0.13 & 0.21 \\
\hline Bolivina alata var. A & 0 & 0.46 & 0.13 & 0 & 0 & 0.59 & 0.96 \\
\hline Bolivina alata var. B & 0 & 0.53 & 0.35 & 0 & 0 & 0.88 & 1.44 \\
\hline Bolivina costata & 0.83 & 0.84 & 0.09 & 0.06 & 0 & 1.82 & 2.97 \\
\hline Bolivina interjuncta & 10.12 & 10.64 & 4.31 & 1.29 & 0.7 & 27.06 & 44.14 \\
\hline Bolivina plicata & 0 & 0.23 & 0.18 & 0 & 0 & 0.41 & 0.67 \\
\hline Bolivina (Loxostomum) boltovskoyi & 0 & 0.08 & 0.09 & 0 & 0 & 0.17 & 0.28 \\
\hline Bolivina (Loxostomum) salvadorensis & 0 & 0.08 & 0 & 0 & 0 & 0.08 & 0.13 \\
\hline Bolivina seminuda & 1.84 & 7.52 & 2.38 & 0.21 & 0.11 & 12.06 & 19.67 \\
\hline Bulimina pupoides & 1.01 & 0.08 & 0.04 & 0.04 & 0.04 & 1.21 & 1.97 \\
\hline Buliminella curta basispinata & 0 & 0.91 & 0 & 0 & 0 & 0.91 & 1.48 \\
\hline Cancris carmenensis & 0.18 & 1.06 & 0 & 0.04 & 0.08 & 1.36 & 2.22 \\
\hline Cassidulina auka & 0.74 & 0.08 & 0.18 & 0.02 & 0.02 & 1.04 & 1.70 \\
\hline Cassidulina crassa & 0.37 & 0.38 & 0.13 & 0 & 0.02 & 0.9 & 1.47 \\
\hline Chilostomella oolina & 0 & 0.08 & 0 & 0 & 0 & 0.08 & 0.13 \\
\hline Cibicidoides wuellerstorfi & 0 & 0 & 0.04 & 0 & 0 & 0.04 & 0.07 \\
\hline Epistominella obesa & 0 & 0 & 0.04 & 0.02 & 0 & 0.06 & 0.10 \\
\hline Ehrenbergina compressa & 0 & 0.08 & 0.04 & 0 & 0 & 0.12 & 0.20 \\
\hline Fursenkoina fusiformis & 0.37 & 1.37 & 1.1 & 0.19 & 0.1 & 3.13 & 5.11 \\
\hline Gyroidina soldanii & 0 & 0 & 0.18 & 0 & 0 & 0.18 & 0.29 \\
\hline Gyroidina soldanii multilocula & 0.64 & 0.3 & 0.09 & 0.02 & 0.04 & 1.09 & 1.78 \\
\hline Haplophragmoides columbiense evolutum & 0 & 0.23 & 0.04 & 0 & 0 & 0.27 & 0.44 \\
\hline Haplophragmoides sphaeriloculum & 0 & 0.23 & 0 & 0 & 0 & 0.23 & 0.38 \\
\hline Hoeglundina elegans & 0 & 0 & 0.09 & 0 & 0 & 0.09 & 0.15 \\
\hline Marsipella granulosa & 0 & 0.23 & 0 & 0 & 0 & 0.23 & 0.38 \\
\hline Pullenia elegans & 0.28 & 0 & 0 & 0 & 0 & 0.28 & 0.46 \\
\hline Pullenia subcarinata & 0 & 0.3 & 0.04 & 0.02 & 0 & 0.36 & 0.59 \\
\hline Pulvinulinella subperuviana & 0.28 & 0 & 0 & 0 & 0 & 0.28 & 0.46 \\
\hline Reophax dentaliniformis & 0.28 & 0 & 0 & 0 & 0 & 0.28 & 0.46 \\
\hline Reophax scorpiurus & 0 & 0.15 & 0.04 & 0 & 0 & 0.19 & 0.31 \\
\hline Suggrunda eckisi & 0 & 0.08 & 0 & 0 & 0 & 0.08 & 0.13 \\
\hline Textularia conica & 0 & 0.08 & 0 & 0 & 0 & 0.08 & 0.13 \\
\hline Uvigerina striata & 1.38 & 0.3 & 0.75 & 0.08 & 0.07 & 2.58 & 4.21 \\
\hline Valvulineria vilardeboana glabra & 0.46 & 0.99 & 0.75 & 0 & 0.01 & 2.21 & 3.60 \\
\hline Virgulina bradyi & 0 & 0 & 0.04 & 0 & 0 & 0.04 & 0.07 \\
\hline Total abundance $\left[\right.$ ind $\mathrm{cm}^{-2}$ ] & 18.95 & 27.82 & 11.35 & 2 & 1.19 & 61.31 & \\
\hline Number of counted specimens & 209 & 364 & 258 & 104 & 99 & & \\
\hline Sample volume $\left[\mathrm{cm}^{3}\right]$ & 8.7 & 21 & 18.13 & 40.9 & 35.6 & & \\
\hline Split & 0.25 & 0.125 & 0.25 & 0.25 & 0.5 & & \\
\hline Population density $\left[\right.$ ind $\mathrm{cm}^{-3}$ ] & 96.1 & 138.7 & 56.9 & 10.2 & 5.6 & & \\
\hline
\end{tabular}


Table A1. Continued.

\begin{tabular}{|c|c|c|c|c|c|}
\hline \multicolumn{6}{|l|}{ M77-1 449-MUC-19 } \\
\hline \multirow[b]{2}{*}{ Living specimens $\mathrm{cm}^{-2}$} & \multicolumn{3}{|c|}{ Sediment depth (mm) } & \multirow[b]{2}{*}{ Total } & \multirow[b]{2}{*}{$\%$} \\
\hline & $0-5$ & $5-10$ & $10-15$ & & \\
\hline Bolivina costata & 11.21 & 3.22 & 0.29 & 14.72 & 5.61 \\
\hline Bolivina plicata & 12.39 & 2.31 & 0.3 & 15 & 5.72 \\
\hline Bolivina seminuda & 173.46 & 8.89 & 2.51 & 184.86 & 70.44 \\
\hline Bulimina pupoides & 9.44 & 0.07 & 0 & 9.51 & 3.62 \\
\hline Buliminella curta & 0.59 & 0 & 0 & 0.59 & 0.22 \\
\hline Buliminella elegantissima limbosa & 0 & 0.56 & 0.03 & 0.59 & 0.22 \\
\hline Buliminella elegantissima tenuis & 11.8 & 1.75 & 0.09 & 13.64 & 5.20 \\
\hline Cancris carmenensis & 12.98 & 1.61 & 0.23 & 14.82 & 5.65 \\
\hline Valvulineria vilardeboana glabra & 4.72 & 0.14 & 0 & 4.86 & 1.85 \\
\hline Ammosphaeroidina grandis & 0 & 0.14 & 0 & 0.14 & 0.05 \\
\hline Bolivina alata var. B & 0 & 0.07 & 0 & 0.07 & 0.03 \\
\hline Cassidulina auka & 0 & 0.07 & 0 & 0.07 & 0.03 \\
\hline Epistominella obesa & 0 & 0.07 & 0 & 0.07 & 0.03 \\
\hline Fursenkoina fusiformis & 0 & 1.05 & 0.09 & 1.14 & 0.43 \\
\hline Nonionides grateloupii & 0 & 1.89 & 0.17 & 2.06 & 0.78 \\
\hline Suggrunda kleinpelli & 0 & 0.14 & 0 & 0.14 & 0.05 \\
\hline Verneuilina bradyi & 0 & 0.14 & 0.02 & 0.16 & 0.06 \\
\hline Pulvinulinella subperuviana & 0 & 0 & 0.02 & 0.02 & 0.01 \\
\hline Total abundance [ind $\mathrm{cm}^{-2}$ ] & 236.59 & 22.12 & 3.72 & 262.43 & \\
\hline Number of counted specimens & 401 & 316 & 248 & & \\
\hline Sample volume $\left[\mathrm{cm}^{3}\right]$ & 27.1 & 29 & 30.7 & & \\
\hline Split & 0.03125 & 0.25 & 1 & & \\
\hline Population density [ind $\mathrm{cm}^{-3}$ ] & 473.5 & 43.6 & 8.1 & & \\
\hline
\end{tabular}

Table A1. Continued.

\begin{tabular}{|c|c|c|c|c|}
\hline \multicolumn{5}{|l|}{ M77-1 583-MUC-65 } \\
\hline \multirow[b]{2}{*}{ Living specimens $\mathrm{cm}^{-2}$} & \multicolumn{2}{|c|}{ Sediment depth (mm) } & \multirow[b]{2}{*}{ Total } & \multirow[b]{2}{*}{$\%$} \\
\hline & $0-10$ & $10-15$ & & \\
\hline Bolivina alata var. B & 0 & 0.04 & 0.04 & 0.01 \\
\hline Bolivina costata & 19.74 & 0.56 & 20.3 & 3.29 \\
\hline Bolivina plicata & 2.82 & 0.24 & 3.06 & 0.50 \\
\hline Bolivina seminuda & 538.62 & 15.56 & 554.18 & 89.83 \\
\hline Bolivina spissa & 0.47 & 0 & 0.47 & 0.08 \\
\hline Bulimina pupoides & 0.47 & 0 & 0.47 & 0.08 \\
\hline Buliminella elegantissima limbosa & 7.99 & 1.88 & 9.87 & 1.60 \\
\hline Buliminella elegantissima tenuis & 2.35 & 0.28 & 2.63 & 0.43 \\
\hline Cancris carmenensis & 0.47 & 0.56 & 1.03 & 0.17 \\
\hline Cassidulina auka & 6.58 & 0.24 & 6.82 & 1.11 \\
\hline Cibicidoides wuellerstorfi & 0.47 & 0 & 0.47 & 0.08 \\
\hline Epistominella obesa & 16.92 & 0.08 & 17 & 2.76 \\
\hline Fursenkoina fusiformis & 0 & 0.44 & 0.44 & 0.07 \\
\hline Trochammina nana & 0 & 0.16 & 0.16 & 0.03 \\
\hline Total abundance [ind $\mathrm{cm}^{-2}$ ] & 596.9 & 20.04 & 616.94 & \\
\hline Number of counted specimens & 1270 & 501 & & \\
\hline Sample volume $\left[\mathrm{cm}^{3}\right]$ & 33.9 & 50.1 & & \\
\hline Split & 0.0625 & 0.25 & & \\
\hline Population density [ind $\mathrm{cm}^{-3}$ ] & 599.4 & 40.0 & & \\
\hline
\end{tabular}


Table A1. Continued.

\begin{tabular}{|c|c|c|c|c|c|c|c|}
\hline \multicolumn{8}{|l|}{ M77-1 459-MUC-25 } \\
\hline \multirow[b]{2}{*}{ Living specimens $\mathrm{cm}^{-2}$} & \multicolumn{5}{|c|}{ Sediment depth $(\mathrm{mm})$} & \multirow[b]{2}{*}{ Total } & \multirow[b]{2}{*}{$\%$} \\
\hline & $0-2$ & $2-4$ & $4-6$ & $6-8$ & $8-10$ & & \\
\hline Ammobaculites agglutinans & 0 & 0.04 & 0.01 & 0.01 & 0 & 0.06 & 0.47 \\
\hline Ammodiscus incertus & 0.03 & 0 & 0 & 0 & 0 & 0.03 & 0.24 \\
\hline Ammodiscus tenuis & 0 & 0.06 & 0 & 0 & 0 & 0.06 & 0.47 \\
\hline Ammomarginulina foliaceus & 0 & 0.71 & 0.01 & 0 & 0 & 0.72 & 5.68 \\
\hline Angulogerina angulosa & 0.05 & 0.06 & 0.03 & 0 & 0 & 0.14 & 1.10 \\
\hline Bolivina alata var. A & 0 & 0.02 & 0 & 0 & 0 & 0.02 & 0.16 \\
\hline Bolivina costata & 0 & 0.08 & 0 & 0 & 0 & 0.08 & 0.63 \\
\hline Bolivina seminuda & 0.01 & 0 & 0 & 0 & 0 & 0.01 & 0.08 \\
\hline Bolivina spissa & 0.06 & 0.59 & 0.62 & 0.39 & 0.51 & 2.17 & 17.11 \\
\hline Bolivinita minuta & 0.26 & 0.59 & 0.05 & 0 & 0 & 0.9 & 7.10 \\
\hline Cassidulina crassa & 0.38 & 0.73 & 0.17 & 0.04 & 0 & 1.32 & 10.41 \\
\hline Cassidulina delicata & 0.13 & 1.35 & 0.24 & 0.07 & 0.01 & 1.8 & 14.20 \\
\hline Cyclammina cancellata & 0.12 & 0.08 & 0.04 & 0 & 0 & 0.24 & 1.89 \\
\hline Eggerella scabra & 0 & 0 & 0.04 & 0 & 0.01 & 0.05 & 0.39 \\
\hline Epistominella obesa & 0 & 0 & 0.02 & 0.01 & 0.01 & 0.04 & 0.32 \\
\hline Epistominella pacifica & 0 & 0.04 & 0.02 & 0 & 0 & 0.06 & 0.47 \\
\hline Fissurina annectens & 0 & 0.02 & 0 & 0 & 0 & 0.02 & 0.16 \\
\hline Fursenkoina fusiformis & 0 & 0.34 & 0.18 & 0.09 & 0.05 & 0.66 & 5.21 \\
\hline Globobulimina pacifica & 0 & 0 & 0.09 & 0.04 & 0 & 0.13 & 1.03 \\
\hline Gyroidina neosoldanii & 0 & 0.02 & 0 & 0 & 0 & 0.02 & 0.16 \\
\hline Gyroidina soldanii & 0.01 & 0 & 0 & 0 & 0 & 0.01 & 0.08 \\
\hline Lagena gracillima & 0 & 0 & 0.01 & 0 & 0 & 0.01 & 0.08 \\
\hline Lagena laevis & 0 & 0 & 0.01 & 0 & 0 & 0.01 & 0.08 \\
\hline Pullenia elegans & 0.01 & 0 & 0 & 0 & 0 & 0.01 & 0.08 \\
\hline Pullenia subcarinata & 0 & 0.04 & 0 & 0 & 0 & 0.04 & 0.32 \\
\hline Quinqueloculina seminula & 0 & 0.04 & 0 & 0 & 0 & 0.04 & 0.32 \\
\hline Reophax apiculatus & 0.26 & 0.83 & 0.03 & 0.01 & 0 & 1.13 & 8.91 \\
\hline Saracenaria stolidota & 0 & 0 & 0.01 & 0 & 0 & 0.01 & 0.08 \\
\hline Uvigerina auberiana & 0.03 & 0.02 & 0 & 0 & 0 & 0.05 & 0.39 \\
\hline Uvigerina canariensis & 0.01 & 0 & 0 & 0.01 & 0 & 0.02 & 0.16 \\
\hline Uvigerina peregrina & 0.72 & 1.31 & 0.18 & 0.17 & 0.01 & 2.39 & 18.85 \\
\hline Valvulina oblonga & 0 & 0.04 & 0.05 & 0.17 & 0.14 & 0.4 & 3.15 \\
\hline Valvulineria vilardeboana glabra & 0 & 0 & 0 & 0 & 0.04 & 0.04 & 0.32 \\
\hline Virgulina schreibersiana & 0 & 0 & 0 & 0 & 0.02 & 0.02 & 0.16 \\
\hline Total abundance [ind $\mathrm{cm}^{-2}$ ] & 2.07 & 7.01 & 1.8 & 0.99 & 0.81 & 12.68 & \\
\hline Number of counted specimens & 157 & 354 & 189 & 108 & 76 & & \\
\hline Sample volume $\left[\mathrm{cm}^{3}\right]$ & 15.8 & 20.5 & 21.2 & 20.2 & 18.1 & & \\
\hline Split & 1 & 0.5 & 1 & 1 & 1 & & \\
\hline Population density [ind $\mathrm{cm}^{-3}$ ] & 9.9 & 34.5 & 8.9 & 5.3 & 4.2 & & \\
\hline
\end{tabular}

Table A1. Continued.

\begin{tabular}{|c|c|c|}
\hline \multicolumn{3}{|l|}{ M77-1 473-MUC-32 } \\
\hline \multicolumn{3}{|c|}{ Sediment depth (mm) } \\
\hline Living specimens $\mathrm{cm}^{-2}$ & $0-5$ & $\%$ \\
\hline Bolivina costata & 77.72 & 14.88 \\
\hline Bolivina plicata & 68.01 & 13.02 \\
\hline Bolivina seminuda & 349.76 & 66.94 \\
\hline Buliminella curta & 4.32 & 0.83 \\
\hline Buliminella elegantissima limbosa & 1.08 & 0.21 \\
\hline Buliminella elegantissima tenuis & 5.4 & 1.03 \\
\hline Cancris carmenensis & 8.64 & 1.65 \\
\hline Cassidulina auka & 1.08 & 0.21 \\
\hline Epistominella obesa & 1.08 & 0.21 \\
\hline Valvulineria vilardeboana glabra & 5.4 & 1.03 \\
\hline Total abundance [ind $\mathrm{cm}^{-2}$ ] & 522.48 & \\
\hline Number of counted specimens & 484 & \\
\hline Sample volume $\left[\mathrm{cm}^{3}\right]$ & 29.6 & \\
\hline Split & 0.015625 & \\
\hline Population density [ind $\mathrm{cm}^{-3}$ ] & 1046.5 & \\
\hline
\end{tabular}

Table A2. Sampling sites for pore water nitrate profiles.

\begin{tabular}{lccc}
\hline Site & $\begin{array}{c}\text { Longitude } \\
(\mathrm{S})\end{array}$ & $\begin{array}{c}\text { Latitude } \\
(\mathrm{W})\end{array}$ & $\begin{array}{c}\text { Water } \\
\text { depth }(\mathrm{m})\end{array}$ \\
\hline M77/1-543/MUC-52 & $11^{\circ} 00.01^{\prime}$ & $77^{\circ} 47.40^{\prime}$ & 79 \\
M77/1-470/MUC-29 & $11^{\circ} 00.02^{\prime}$ & $77^{\circ} 56.60^{\prime}$ & 145 \\
M77/1-573/MUC-61 & $11^{\circ} 09.09^{\prime}$ & $78^{\circ} 05.05^{\prime}$ & 309 \\
M77-1-449/MUC-19 & $11^{\circ} 00.01^{\prime}$ & $78^{\circ} 09.97^{\prime}$ & 319 \\
M77/1-481/MUC-33 & $11^{\circ} 00.00^{\prime}$ & $78^{\circ} 14.19^{\prime}$ & 376 \\
M77/1-601/MUC-71 & $11^{\circ} 12.05^{\prime}$ & $78^{\circ} 10.08^{\prime}$ & 394 \\
M77/1-456/MUC-22 & $11^{\circ} 00.013^{\prime}$ & $78^{\circ} 19.23^{\prime}$ & 465 \\
M77/1-516/MUC-40 & $11^{\circ} 00.00^{\prime}$ & $78^{\circ} 20.00^{\prime}$ & 512 \\
M77/1-488/MUC-39 & $11^{\circ} 00.02^{\prime}$ & $78^{\circ} 23.17^{\prime}$ & 579 \\
M77/1-459/MUC-25 & $11^{\circ} 00.03^{\prime}$ & $78^{\circ} 35.60^{\prime}$ & 697 \\
M77/1-445/MUC-15 & $10^{\circ} 59.997^{\prime}$ & $78^{\circ} 30.022^{\prime}$ & 928 \\
M77/1-549/MUC-53 & $10^{\circ} 59.807^{\prime}$ & $78^{\circ} 31.266^{\prime}$ & 1005 \\
\hline
\end{tabular}




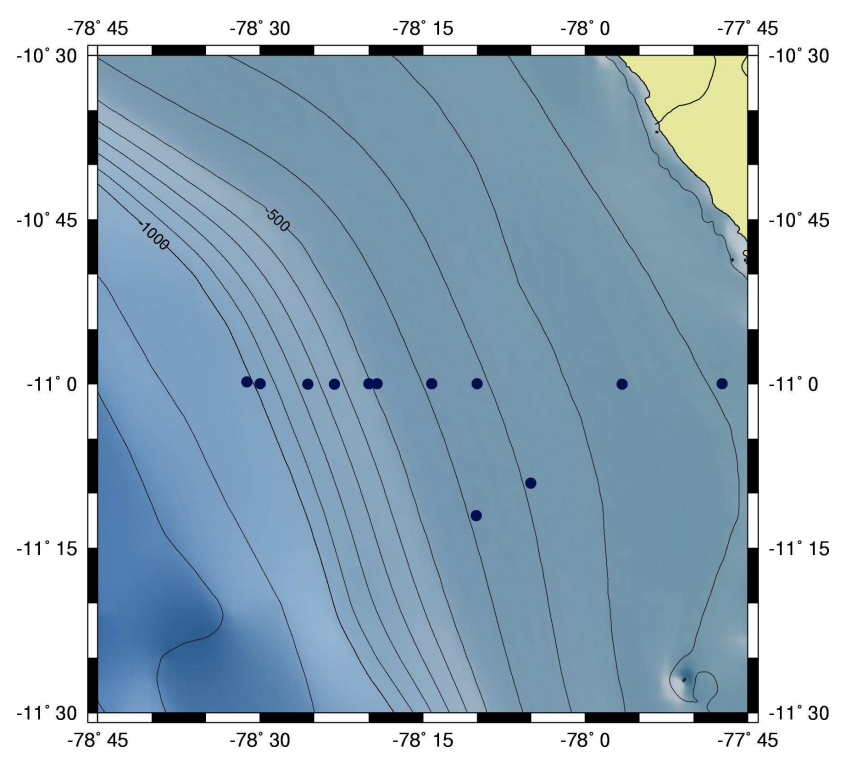

Fig. A1. Map of sampling sites for pore water nitrate profiles.

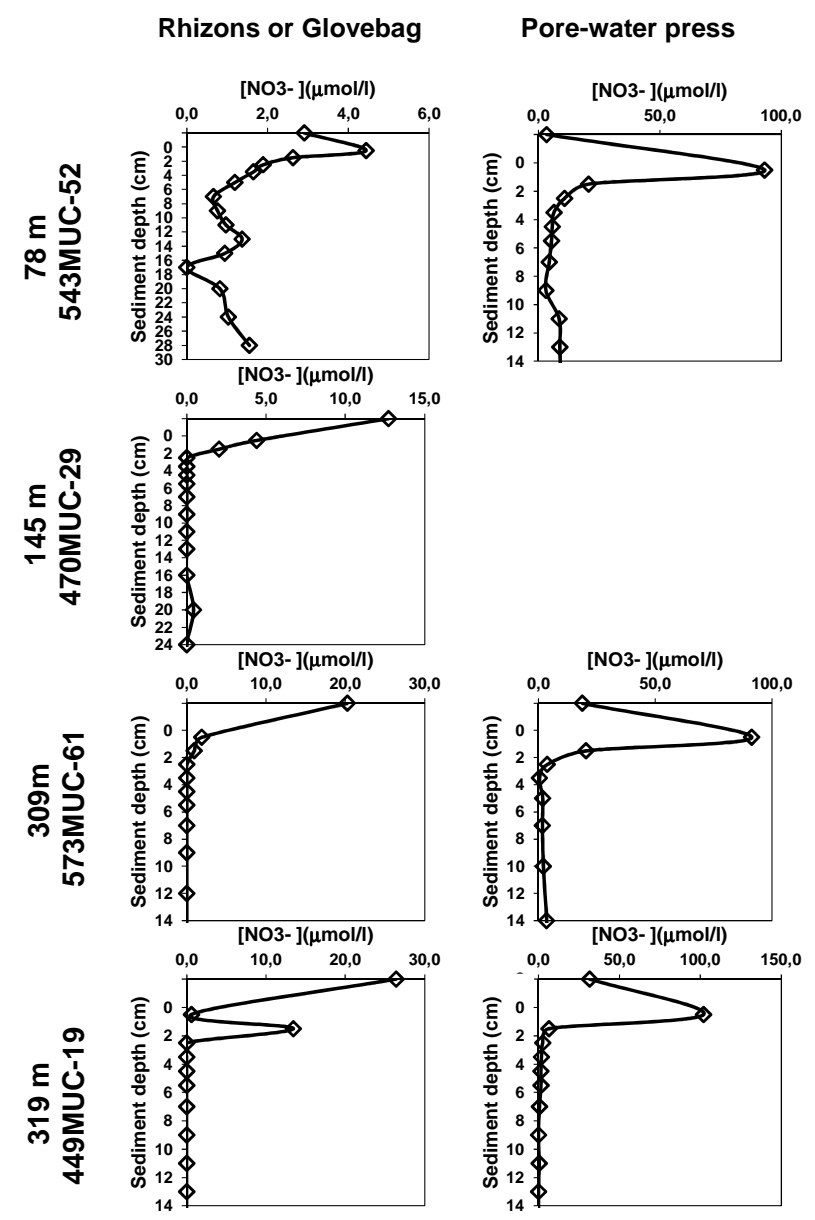

Fig. A2. Pore water nitrate profiles at different water depths along the Peruvian OMZ, including bottom water nitrate concentrations. Profiles on the left represent data from cores sampled with rhizons or in a glove bag. Profiles on the right represent data from cores sampled with a pore water press. Information about the sampling sites is shown in Table A2 . 


\section{Rhizons or Glovebag}

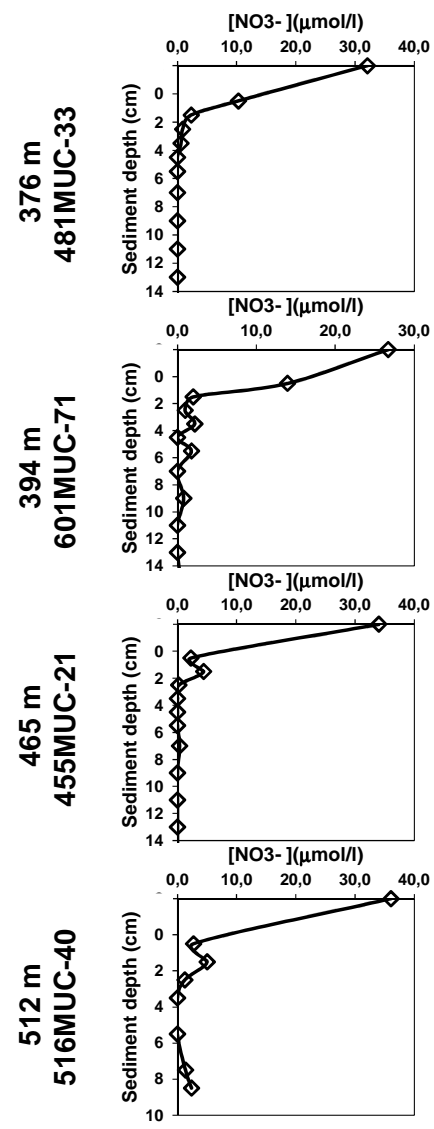

Pore-water press

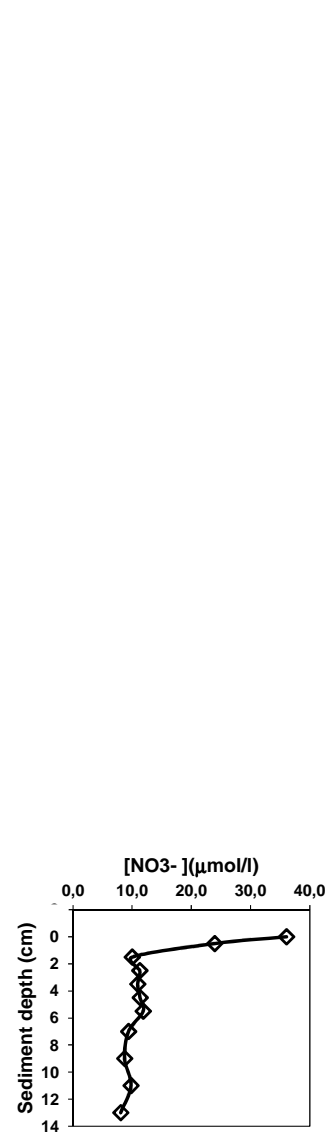

Rhizons or Glovebag

Pore-water press
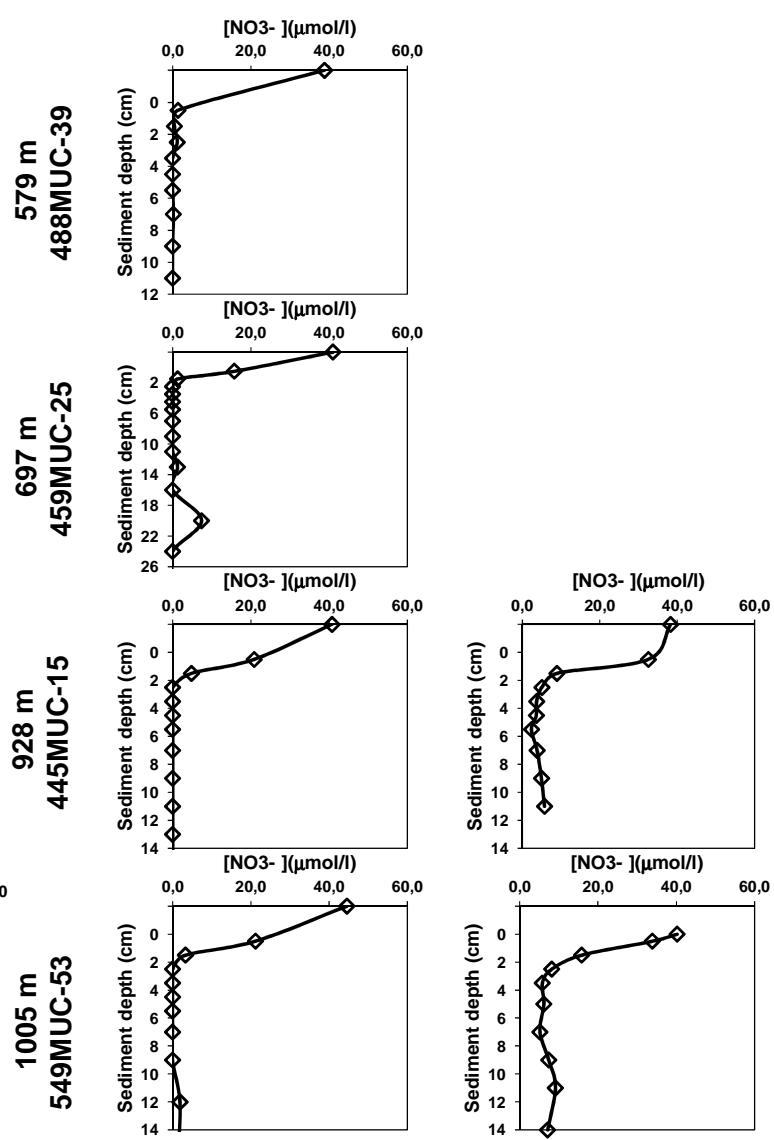

Fig. A2. Continued.

Acknowledgements. We thank Anna Noffke, Lisa Bohlen, Florian Scholz, Bettina Domeyer, Meike Dibbern, Renate Ebinghaus and Sonja Kriwanek for bottom and pore water nitrate and oxygen measurements. Volker Liebetrau supported this study with inspiring discussions. The scientific party on R/V Meteor cruise M77 is acknowledged for their general support and help with multicorer operation and sampling. Also we thank Patrick Grunert and an anonymous reviewer, whose comments improved the previous version of this manuscript considerably. The Deutsche Forschungsgemeinschaft (DFG), provided funding through SFB 754 "Climate-Biogeochemistry Interactions in the Tropical Ocean".

The service charges for this open access publication have been covered by a Research Centre of the Helmholtz Association.

Edited by: J. Middelburg

\section{References}

Arrigo, K. R.: Marine microorganisms and global nutrient cycles, Nature, 437, 349-355, 2005.
Bernhard, J. M.: Postmortem vital staining in benthic foraminifera: duration and importance in population and distributional studies, J. Foramin. Res., 18, 143-146, 1988.

Bernhard, J. M.: Distinguishing live from dead foraminifera: methods review and proper applications, Micropaleontology, 46 (Suppl. 1), 38-46, 2000.

Bernhard, J. M. and Reimers, C. E.: Benthic foraminiferal population fluctuations related to anoxia - Santa Barbara Basin, Biogeochemistry, 15, 127-149, doi:10.1007/BF00003221, 1991.

Bernhard, J. M., Visscher, P. T., and Bowser, S. S.: Sub-millimiter life positions of bacteria, protists, and metazoans in laminated sediments of the Santa Barbara Basin, Limnol. Oceanogr., 48, 813-828, 2003.

Bernhard, J. M., Casciotti, K. L., McIlvin, M. R., Beaudoin, D. J., Visscher, P. T., and Edgcomb, V. P.: Potential importance of physiologically diverse benthic foraminifera in sedimentary nitrate storage and respiration, J. Geophys. Res., 117, G03002, doi:10.1029/2012JG001949, 2012a.

Bernhard, J. M., Edgcomb, V. P., Casciotti, K. L., Mcllvin, M. R., and Beaudoin, D. J.: Denitrification likely catalyzed by endobionts in an allogromiid foraminifer, ISME J., 6, 951-960, 2012b.

Bohlen, L., Dale, A. W., Sommer, S., Mosch, T., Hensen, C., Noffke, A., Scholz, F., and Wallmann, K.: Benthic nitogen cycling 
traversing the Peruvian oxygen minimum zone, Geochim. Cosmochim. Ac., 75, 6094-6111, 2011.

Cabrita, M. T. and Brotas, V.: Seasonal variation in denitrification and dissolved nitrogen fluxes in intertidal sediments of the Tagus estuary, Portugal, Mar. Ecol.-Prog. Ser., 202, 51-65, 2000.

Caralp, M., Lamy, A., and Pujos, M.: Contribution a la connaissance de la distribution bathymétrique des Foraminifères dans le golfe de Gascone, Revista Española de Micropaleontología, 2, 55-84, 1970.

Corliss, B. H.: Microhabitats of benthic foraminifera within deepsea sediments, Nature, 314, 435-438, 1985.

Den Dulk, M., Reichart, G. J., Memon, G. M., Roelofs, E. M. P., Zachariasse, W. J., and van der Zwaan, G. J.: Benthic foraminiferal response to variations in surface water productivity and oxygenation in the northern Arabian Sea, Mar. Micropaleontol., 35, 43-66, 1998.

Finlay, B. J., Span. A. S. W., and Harman, J. M. P.: Nitrate respiration in primitive eukaryotes, Nature, 303, 333-335, 1983.

Glock, N., Eisenhauer, A., Milker, Y., Liebetrau, V., Schönfeld, J., Mallon, J., Sommer, S., and Hensen, C.: Environmental influences on the pore-density in tests of Bolivina spissa, J. Foramin. Res., 41, 22-32, 2011.

Glock, N., Schönfeld, J. and Mallon, J.: The functionality of pores in benthic foraminifera and bottom water oxygenation. A Review, in ANOXIA: Evidence for eukaryote survival and paleontological strategies, Cellular Origin, Life in Extreme Habitats and Astrobiology 21, edited by: Altenbach, A. V., Bernhard, J. M., and Seckbach, J., Springer Science + Business Media, 2011, 537552, doi:10.1007/978-94-007-1896-8_28, 2012.

Glud, R. N., Thamdrup, B., Stahl, H., Wenzhoefer, F., Glud, A., Nomaki, H., Oguri, K., Revsbech, N. P., and Kitazato, H.: Nitrogen cycling in a deep ocean margin sediment (Sagami Bay, Japan), Limnol. Oceanogr., 54, 723-734, 2009.

Gooday, A. J., Bernhard, J. M., Levin, L. A., and Suhr, S. B.: Foraminifera in the Arabian Sea Oxygen minimum zone and other oxygen deficient settings: taxonomic composition, diversity, and relation to metazoan faunas, Deep-Sea Res. Pt. II, 47, 25-54, 2000.

Graco, M., Farias, L., Molina, V., Gutierrez, D., and Nielsen, L. P.: Massive developments of microbial mats following phytoplankton blooms in a naturally eutrophic bay: Implications for nitrogen cycling, Limnol. Oceanogr., 46, 821-832, 2001.

Grasshoff, K., Ehrhardt, M., and Kremling, K.: Methods of Seawater Analysis, Wiley-VCH, Weinheim, 1999.

Gruber N.: The dynamics of the marine nitrogen cycle and its influence on atmospheric $\mathrm{CO}_{2}$ variations, in: Carbon Cycle and Climate, edited by: Follows, M. and Oguz, T., The Ocean, NATO ASI Series, Kluwer Academic, Dordrecht, 97-148, 2004.

Gruber, N. and Sarmiento, J. L.: Global patterns of marine nitrogen fixation and denitrification, Global Biogeochem. Cy., 11, 235266, 1997.

Guitiérrez, D., Enríquez, E., Purca, S., Quipúzcoa, L., Marquina, R., Flores, G., and Graco, M.: Oxygenation episodes on the continental shelf of central Peru: Remote forcing and benthic ecosystem response, Prog. Oceanogr., 79, 177-189, 2008.

Haake, F. W.: Benthic foraminifera of surface samples and sediment cores off Senegal and Gambia, West Africa, in: Benthische Foraminiferen in Oberflächen-Sedimenten und Kernen des Ostatlantiks vor Senegal/Gambia (Westafrika), edited by: Haake, F.
W., Meteor Forschungsergebnisse, Deutsche Forschungsgemeinschaft, Reihe C Geologie und Geophysik, Gebrüder Bornträger, Berlin, Stuttgart, C32, 1-29, doi:10.1594/PANGAEA.548467, 1980.

Heinz, P., Ruepp, D., and Hemleben, C.: Benthic foraminifera assembleges at Great Meteor Seamount, Mar. Biol., 144, 985-998, doi:10.1007/s00227-003-1257-7, 2004.

Høgslund, S., Revsbech, N. P. Cedhagen, T. Nielsen, L. P., and Gallardo, V. A.: Denitrification, nitrate turn over, and aerobic respiration by benthic foraminiferans in the oxygen minimum zone off Chile, J. Exp. Mar. Biol. Ecol., 359, 85-91, 2008.

Jannink, N. T., Zachariasse, W. J., and van der Zwaan, G. J.: Living (Rose bengal stained) Benthic foraminifera from the Pakistan continental margin (northern Arabian Sea), Deep-Sea Res. Pt. I, 45, 1483-1513, 1998.

Kamp, A., de Beer, D., Nitsch, J. L., Lavik, G., and Stief, P.: Diatoms respire nitrate to survive dark and anoxic conditions, P. Natl. Acad. Sci. USA, 108, 5649-5654, doi:10.1073/pnas.1015744108, 2011.

Kitazato, H.: Foraminiferal microhabitats in four marine environments around Japan, Mar. Micropaleontol., 24, 29-41, 1994.

Kuypers, M. M. M., Sliekers, A. O., Lavik, G., Schmid, M., Jørgensen, B. B., Kuenen, J. G., Sinninghe Damsteì, J. S., Strous, M., and Jetten, M. S. M.: Anaerobic ammonium oxidation by anammox bacteria in the Black Sea, Nature, 422, 608-611, doi:10.1038/nature01472, 2003.

Lam, P., Lavik, G., Jensen, M. M., van de Vossenberg, J., Schmid, M., Woebken, D., Gutiérrez, D., Amann, R., Jetten, M. S. M., and Kuypers, M. M. M.: Revising the nitrogen cycle in the Peruvian oxygen minimum zone, P. Natl. Acad. Sci. USA, 106, 47524757, 2009.

Lutze, G. F.: Relative abundance of live (Rose Bengal stained) benthic foraminifera in the small size fraction of surface sediment off NW Africa (Table 3), in: Depth distribution of benthic foraminifera on the continental margin off $\mathrm{NW}$ Africa, edited by: Lutze, G. F., Meteor Forschungsergebnisse, Deutsche Forschungsgemeinschaft, Reihe C Geologie und Geophysik, Gebrüder Bornträger, Berlin, Stuttgart, C32, 31-80 doi:10.1594/PANGAEA.536260, 1980.

Lutze, G. F. and Altenbach, A. V.: Technik und Signifikanz der Lebendfärbung benthischer Foraminiferen in Bengalrot, Geologisches Jahrbuch, Reihe A, 128, 251-265, 1991.

Mallon, J.: Benthic foraminifera of the Peruvian and Ecuadorian Continental Margin, dissertation, Geomar Helmholtz Centre for Ocean Research, Kiel, 2012.

Mallon, J., Glock, N., and Schönfeld, J.: The response of benthic foraminifera to low-oxygen conditions of the Peruvian oxygen minimum zone, in: ANOXIA: Evidence for eukaryote survival and paleontological strategies, Cellular Origin, Life in Extreme Habitats and Astrobiology 21, edited by: Altenbach, A. V., Bernhard, J. M., and Seckbach, J., Springer Science + Business Media, 305-321, doi:10.1007/978-94-007-1896-8_16, 2012.

Mosch, T., Sommer, S., Dengler, M., Noffke, A., Bohlen, L., Pfannkuche, O., Liebetrau, V., and Wallmann, K.: Factors influencing the distribution of epibenthic megafauna across the Peruvian oxygen minimum zone, Deep-Sea Res. Pt. I, 68, 123-135, doi:10.1016/j.dsr.2012.04.014, 2012.

Murray, J. W.: The niche of benthic foraminifera, critical thresholds and proxies, Mar. Micropaleontol., 41, 1-7, 2001. 
Murray, J. W. and Bowser, S. S.: Mortality, protoplasm decay rate, and reliability of staining techniques to recognize 'living' foraminifera: a review, J. Foramin. Res., 30, 66-77, 2000.

Noffke, A., Hensen, C., Sommer, S., Scholz, F., Bohlen, L., Mosch, T., Graco, M., and Wallmann, K.: Benthic iron and phosphorus fluxes across the Peruvian oxygen minimum zone, Limnol. Oceanogr., 57, 851-867, 2012.

Ohga, T. and Kitazato, H.: Seasonal changes in bathyal foraminiferal populations in response to the flux of organic matter (Sagami Bay, Japan), Terra Nova, 9, 33-37, 1997.

Otto, G. H.: Comparative tests of several methods of sampling heavy mineral concentrates, J. Sediment. Petrol., 3, 30-39, 1933.

Phleger, F. B. and Soutar, A.: Production of benthic foraminifera in three east Pacific oxygen minima, Micropaleontology, 19, 110115, 1973.

Pierotti, D. and Rasmussen, R. A.: Nitrous oxide measurements in the eastern tropical Pacific Ocean, Tellus, 32, 56-72, 1980.

Piña-Ochoa, E., Høgslund, S., Geslin, E., Cedhagen, T., Revsbech, N. P., Nielsen, L. P., Schweizer, M., Jorissen, F., Rysgaard, S., and Risgaard-Petersen, N.: Widespread occurence of nitrate storage and denitrification among Foraminifera and Gromiida, P. Natl. Acad. Sci. USA, 107, 1148-1153, 2010a.

Piña-Ochoa, E., Koho, K. A., Geslin, E., and Risgaard-Petersen, N.: Survival and life strategy of the foraminiferan Globobulimina turgida through nitrate storage and denitrification, Mar. Ecol.Prog. Ser., 417, 39-49, 2010b.

Prokopenko, M. G., Sigman, D. M., Berelson, W. M., Hammond, D. E., Barnett, B., Chong, L., and Townsend-Small, A.: Denitrification in anoxic sediments supported by biological nitrate transport, Geochim. Cosmochim. Ac., 75, 7180-7199, 2011.

Reimers, C. E., Ruttenberg, K. C., Canfield, D. E., Christiansen, M. B., and Martin, J. B.: Porewater pH and authigenic phases formed in the uppermost sediments of the Santa Barbara Basin, Geochim. Cosmochim. Ac., 60, 4037-4057, doi:10.1016/S00167037(96)00231-1, 1996.

Revsbech, N. P., Larsen, L. H., Gundersen, J., Dalsgaard, T., Ulloa, O., and Thamdrup, B.: Determination of ultra-low oxygen concentrations in oxygen minimum zones by the STOX sensor, Limnol. Oceanogr.-Meth., 7, 371-381, 2009.

Risgaard-Petersen, N., Langezaal, A. M., Ingvardsen, S., Schmid, M. C., Jetten, M. S., Op den Camp, H. J. M., Derksen, J. W. M., Piña-Ochoa, E., Eriksson, S. P., Nielsen, L. P., Revsbech, N. P., Cedhagen, T., and van der Zwaan, G. J.: Evidence for complete denitrification in a benthic foraminifer, Nature, 443, 93-96, 2006.

Ryabenko, E., Kock, A., Bange, H. W., Altabet, M. A., and Wallace, D. W. R.: Contrasting biogeochemistry of nitrogen in the Atlantic and Pacific Oxygen Minimum Zones, Biogeosciences, 9, 203215, doi:10.5194/bg-9-203-2012, 2012.

Rysgaard, S., Fossing, H., and Jensen, M. M.: Organic matter degradation through oxygen respiration, denitrification, and manganese, iron, and sulfate reduction in marine sediments (the Kattegat and the Skagerrak), Ophelia, 55, 77-91, 2001.

Schmiedl, G., Mackensen, A., and Müller, P. J.: Recent benthic foraminifera from the eastern South Atlantic Ocean: Dependance on food supply and water masses, Mar. Micropaleontol., 32, 249287, 1997.

Schönfeld, J.: History and development of methods in Recent benthic foraminiferal studies, J. Micropaleontol., 31, 53-72, 2012.
Schumacher, S., Jorissen, F. J., Dissard, D., Larkin, K. E., and Gooday, A. J.: Live (Rose Bengal stained) and dead benthic foraminifera from the oxygen minimum zone of the Pakistan continental margin (Arabian Sea), Mar. Micropaleontol., 62, 4573, 2007.

Shoun, H. and Tanimoto, T.: Denitrification by the fungus Fusarium oxysporum and involvement of cytochrome P-450 in the respiratory nitrite reduction, J. Biol. Chem., 266, 11078-11082, 1991.

Sommer, S., Linke, P., Pfannkuche, O., Schleicher, T., Schneider v. Deimling, J., Reitz, A., Haeckel, M., Flögel, S., and Hensen, C.: Seabed methane emissions and the habitat of frenulate tubeworms on the Captain Arutyunov mud volcano (Gulf of Cadiz), Mar. Ecol.-Prog. Ser., 382, 69-86, doi:10.3354/meps07956, 2009.

Sommer S., McGinnis, D. F., Linke, P., Camilli, R., Mosch, T., and Pfannkuche, O.: Life at the edge - oscillating lower boundary of the Peruvian oxygen minimum zone, Eos Transactions AGU, 91, Ocean Science Meeting Supplementary, Abstract BO24C08, 2010.

Tengberg, A., Hovdenes, J., Andersson, H. J. Brocandel, O., Diaz, R., Hebert, D., Arnerich, T., Huber, C., Körtzinger, A., Khripounoff, A., Rey, F., Rönning, C., Schimanski, J., Sommer, S., and Stangelmayer, A.: Evaluation of a lifetime-based optode to measure oxygen in aquatic systems, Limnol. Oceanogr.-Meth., 4, 7-17, 2006.

Thamdrup B. and Dalsgaard T.: Production of N2 through anaerobic ammonium oxidation coupled to nitrate reduction in marine sediments, Appl. Environ. Microb., 68, 1312-1318, 2002.

Thamdrup, B., Dalsgaard, T. and Revsbech, N. P., Widespread functional anoxia in the oxygen minimum zone of the Eastern South Pacific, Deep-Sea Res. Pt. I, 65, 36-45, doi:10.1016/j.dsr.2012.03.001, 2012.

Timm, S.: Rezente Tiefsee-Benthosforaminiferen aus Oberflächensedimenten des Golfes von Guinea (Westafrika): Taxonomie, Verbreitung, Oekologie und Korngrössenfraktionen $=$ Recent deep-sea benthic foraminifera from surface sediments of Gulf of Guinea (Westafrika): taxonomy, distributions, ecology and grain size fractions, dissertation, GeologischPaläontologisches Institut und Museum, Christian-AlbrechtsUniversität, 1992.

Uchio, T.: Ecology of living benthonic foraminifera from the San Diego, California, Area, Cushman Foundation for Foraminiferal Research, Special Publication, 5, 1-72, 1960.

Usuda, K., Toritsuka, N., Matsuo, Y., Kim, D. H., and Shoun, H.: Denitrification by the fungus Cylindrocarpon tonkinense: Anaerobic cell growth and two isozyme forms of cytochrome P-450nor, Appl. Environ. Microb., 61, 883-889, 1995.

Van de Graaf, A. A., Mulder, A., de Bruijn, P., Jetten, M. S. M., and Kuenen, J. G.: Anaerobic oxidation of ammonium is a biologically mediated process, Appl. Environ. Microb., 1, 1246-1251, 1995.

Walker, D. A., Linton, A. E., and Schafer, C. T.: Sudan Black B: A superior stain to Rose Bengal for distinguishing living from nonliving foraminifera, J. Foramin. Res., 4, 205-215, 1974.

Zumft, W. G.: Cell biology and molecular basis of denitrification, Microbiol. Mol. Biol. R., 61, 533-616, 1997. 